Article

\title{
Dark Septate Endophytic Fungi Associated with Sugarcane Plants Cultivated in São Paulo, Brazil
}

\author{
Rosalba Ortega Fors ${ }^{1, *(\mathbb{D}}$, Camila Maistro Patreze ${ }^{2}{ }^{\mathbb{D}}$, Ricardo Luis Louro Berbara ${ }^{1} \mathbb{D}$, \\ Marco Aurélio Carbone Carneiro ${ }^{3}$ and Orivaldo José Saggin-Júnior ${ }^{4}$ \\ 1 Soil Science Department, Federal Rural University of Rio de Janeiro (UFRRJ), BR-465, km 07, \\ Seropédica 23890-000, Rio de Janeiro, Brazil; rberbara@hotmail.com \\ 2 Botany Department, Federal University of Rio de Janeiro State (UNIRIO), Pasteur Avenue, 458, \\ Urca 22290-240, Rio de Janeiro, Brazil; camila.m.patreze@unirio.br \\ 3 Soil Science Department, University Campus, Federal University of Lavras (UFLA), Lavras 37200-000, \\ Minas Gerais, Brazil; marcocarbone@dcs.ufla.br \\ 4 Brazilian Agricultural Research Corporation (Embrapa), BR-465, km 07, Seropédica 23891-000, \\ Rio de Janeiro, Brazil; orivaldo.saggin@embrapa.br \\ * Correspondence: fors.rosalba@gmail.com
}

Received: 30 June 2020; Accepted: 10 September 2020; Published: 14 September 2020

\begin{abstract}
Dark septate endophytes (DSEs) constitute a polyphyletic group within the Ascomycota, with global distribution and a wide range of host plant species. The present study evaluated the diversity of DSE in sugarcane roots of the varieties RB867515, RB966928, and RB92579, and four varieties of not commercialized energy cane. A total of 16 DSE strains were isolated, mostly from the varieties RB966928 and RB867515, with six and five isolates, respectively. Just one of the four energy cane varieties had fungi with DSE appearance. The analyses of the DNA sequences from the internal transcribed spacer (ITS) and the large subunit (LSU), in association with the micromorphology of the isolates, allowed the differentiation of the 16 isolates in at least five species, within the families Periconiaceae, Pleosporaceae, Lentitheciaceae, Vibrisseaceae, and Apiosporaceae and the orders Pleosporales, Helotiales, and Xylariales. The order Pleosporales represented $80 \%$ of the isolates, and the species Periconia macrospinosa, with six isolates, accounted for the highest isolation frequency. The results confirm the natural occurrence of the DSE symbiosis in sugarcane varieties and the generalist character of these fungi as some of the detected species have already been reported associated with other host plants, ecosystems, and regions of the world.
\end{abstract}

Keywords: root-associated fungi; DSE; Saccharum sp.; symbionts; Ascomycota

\section{Introduction}

Dark septate endophytes (DSEs) represent a polyphyletic group of fungal genera and species with cryptic diversity within the phylum Ascomycota [1,2]. These fungi associate with plants, colonizing inter and intracellular spaces of the root cortex and forming melanized structures, including septate hyphae and microsclerotia [3]. Although studies involving this symbiosis date back to the early twentieth century [4], research and publications about DSE concentrate in the last three decades [5]. Even with the recent advances, new studies are still required to conclude about the taxonomic and functional diversity of this fungal group [2,6]. There are currently only around 30 species of fungal species described as DSEs [7] mainly distributed in the orders Pleosporales and Helotiales, and with lower representation of genera within orders such as Capnodiales, Eurotiales, Sordariales, and Xylariales, among others [1,5].

Numerous studies indicate wide distribution and occurrence of DSEs in different ecosystems [4] and interaction with diverse plant species [8-12]. Apparently, there is an overlap of the ecological 
niche occupied by DSE and arbuscular mycorrhizal fungi. Initially, DSEs were considered "pseudo-mycorrhizae" (see revision published by Jumpponen \& Trappe [4]. However, DSEs are currently distinguished from mycorrhizal fungi by the absence of specific intraradicular structures for the exchange of carbon and nutrients, such as arbuscules, pelotons, and Hartig net, and for the high variability of host responses regarding this symbiosis [2].

Several fungi within the DSE have been reported as promoters of plant growth through improved nutritional status of their host plants $[13,14]$ and increased tolerance to abiotic and biotic stress such as drought [15,16], trace element toxicity [17,18], salinity [19], and phytopathogens [20-22]. However, neutral or even negative results derived from DSE interaction with roots have also been observed [23,24]. Factors associated with the physiological status of the host plant, environmental conditions, nitrogen sources, and even preference between isolates/species of DSE and plant genotype have been proven to drive this association through the mutualism-parasitism continuum $[6,23,25,26]$.

Even though results regarding plant growth promotion by these fungi are still inconsistent, they suggest relevant biotechnological potential for the development of biological inoculants for agriculture, which could increase crop resistance and adaptation to climate change. However, additional research is fundamental to overcome current gaps related to the diversity and functional role of DSE in crops, as there are not many studies that have addressed this topic $[15,24,27,28]$. In Brazil, sugarcane is among the most important crops, with the country considered to be the main global sugarcane producer and the state of São Paulo the largest sugarcane hub in the country [29]. Nevertheless, studies reporting the occurrence of DSE fungi and/or their interaction with sugarcane are almost inexistent, not only in Brazil, but globally. Up to date, only studies regarding general fungal endophytic communities have been published for this crop. Fungi of the orders Polyporales and Eurotiales, and unidentified ascomycetous and basidiomycetous, have been documented to integrate the community of fungal root endophytes in sugarcane grown in Brazil $[30,31]$. Specifically for DSEs, recent studies have verified the occurrence of typical structures such as microsclerotia and chlamydospores in sugarcane roots, also colonized by arbuscular mycorrhizal fungi [32,33]. The results suggest that, while DSE colonization levels in plants of this species can be high [33], they seem to decrease with the age of the plant, as supported by the results obtained in Australia when comparing sugarcane plants from first and second ratoon [32].

Considering all the information referred to previously, the isolation and identification of DSE associated with sugarcane might lead to a better understanding of the importance of this symbiosis for the crop. This way, the present study is one of the first to specifically approach DSE fungi associated with Saccharum sp., aiming to isolate and identify DSE species associated with sugarcane varieties grown in the region of Quatá, São Paulo, Brazil. This work also creates the basis for future research involving the function and possible biotechnological application of these symbionts in the sugarcane culture.

\section{Materials and Methods}

\subsection{Field Sampling and Isolation of Dark Septate Endophytic Fungi}

Sampling of sugarcane plants was conducted in June 2016 in sugarcane fields of Açucareira Quatá S/A, a Zilor industry, located in the state of São Paulo, Brazil $\left(-22.250137^{\circ}-50.653517^{\circ}\right)$ (Figure 1). Soils within the sampled fields are classified as Latossolo Vermelho, Argissolo Vermelho, and Argissolo Amarelo of medium texture according to the Brazilian System of Soil Classification [34]. 

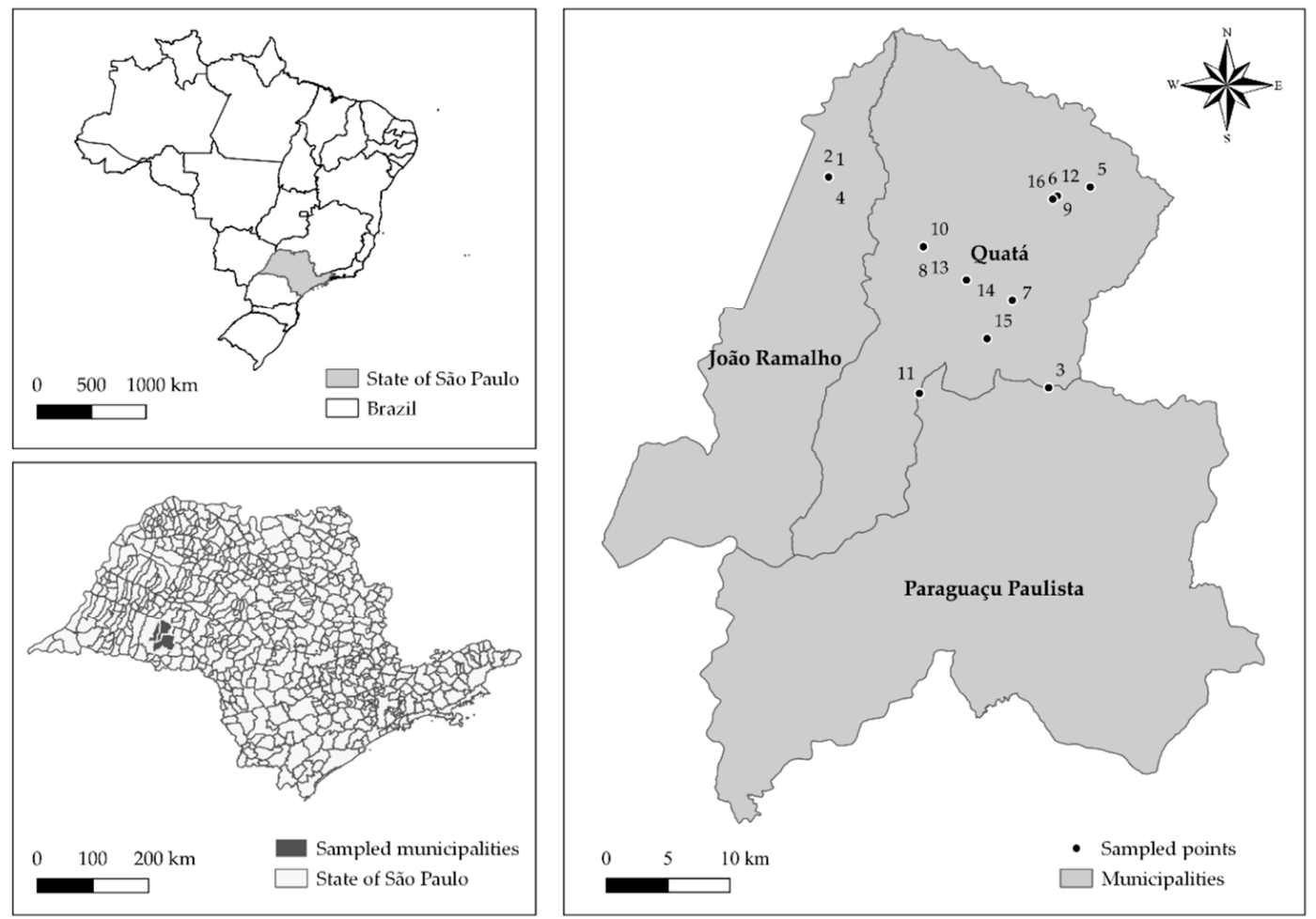

Figure 1. Geographical localization of sugarcane fields (1-16) in the state of São Paulo, Brazil, where roots from adult sugarcane clumps were sampled for the isolation of dark septate endophytes (DSEs). Point georeferences: $1\left(22.136289^{\circ} \mathrm{S} 50.756884^{\circ} \mathrm{W}\right), 2\left(22.136231^{\circ} \mathrm{S} 50.756927^{\circ} \mathrm{W}\right), 3\left(22.302731^{\circ} \mathrm{S}\right.$ $\left.50.583676^{\circ} \mathrm{W}\right), 4\left(22.136308^{\circ} \mathrm{S} 50.756930^{\circ} \mathrm{W}\right), 5\left(22.144143^{\circ} \mathrm{S} 50.550939^{\circ} \mathrm{W}\right), 6\left(22.153620^{\circ} \mathrm{S}\right.$ $\left.50.580430^{\circ} \mathrm{W}\right), 7\left(22.233203^{\circ} \mathrm{S} 50.612332^{\circ} \mathrm{W}\right), 8\left(22.191161^{\circ} \mathrm{S} 50.682404^{\circ} \mathrm{W}\right), 9\left(22.153670^{\circ} \mathrm{S}\right.$ $\left.50.580390^{\circ} \mathrm{W}\right), 10\left(22.191110^{\circ} \mathrm{S} 50.682444^{\circ} \mathrm{W}\right), 11\left(22.307150^{\circ} \mathrm{S} 50.685457^{\circ} \mathrm{W}\right), 12\left(22.151228^{\circ} \mathrm{S}\right.$ $\left.50.576790^{\circ} \mathrm{W}\right), 13\left(22.191096^{\circ} \mathrm{S} 50.682333^{\circ} \mathrm{W}\right), 14\left(22.217306^{\circ} \mathrm{S} 50.648372^{\circ} \mathrm{W}\right), 15\left(22.264116^{\circ} \mathrm{S}\right.$ $\left.50.632208^{\circ} \mathrm{W}\right)$, and $16\left(22.153690^{\circ} \mathrm{S} 50.580440^{\circ} \mathrm{W}\right)$.

For the field sampling, a total of 16 sugarcane adult clumps were dug and plucked. This way, one clump was removed from each of the sampled points (1-16) (Table 1), and four clumps were sampled for each of the following varieties: RB867515, RB92579, and RB966928. Additionally, another four clumps from not commercialized energy cane varieties $(\mathrm{CE})$ were sampled, one clump for each of the CE varieties, considered here as CE1, CE2, CE3, and CE4.

Once in the laboratory, fine and healthy roots were separated from each clump, washed with tap water, and cut into $2-3 \mathrm{~cm}$ segments. These root segments were superficially disinfected by successive immersion in sodium hypochlorite $2.5 \%$ (Alphatec) for $2 \mathrm{~min}$, hydrogen peroxide (33\%) (Impex) for $1 \mathrm{~min}$, and sterile distilled water (five consecutive times) [35]. Subsequently, using a sterile scalpel and tweezers, the ends of the segments were cut and discarded. The preserved parts were then subdivided into pieces of approximately $3-5 \mathrm{~mm}$, and distributed (one piece per drop) in Petri dishes $\left(9 \mathrm{~cm}\right.$ in diameter) containing 30-40 drops of Gel-Gro ${ }^{\circledR}$ (Sigma-Aldrich ${ }^{\circledR}$, St. Louis, $\mathrm{MO}$, USA) $\left(3.5 \mathrm{~g} \mathrm{~L}^{-1}\right)$ supplemented with $\mathrm{MgSO}_{4}\left(0.3 \mathrm{~g} \mathrm{~L}^{-1}\right)$, gentamicin sulfate (Sigma-Aldrich ${ }^{\circledR}$ ) $\left(0.25 \mathrm{mg} \mathrm{L}^{-1}\right)$, and streptomycin sulfate (Sigma-Aldrich $\left.{ }^{\circledR}\right)\left(0.25 \mathrm{mg} \mathrm{L}^{-1}\right)$, with $\mathrm{pH}$ adjusted to 6.0 [36]. Additionally, five root pieces from each sample were placed in Petri dishes $(9 \mathrm{~cm}$ in diameter) containing malt extract agar (MEA) medium (malt extract (Sigma Aldrich ${ }^{\circledR}$ ) $20 \mathrm{~g} \mathrm{~L}^{-1}$, dextrose (Sigma) $20 \mathrm{~g} \mathrm{~L}^{-1}$, peptone (Sigma) $1 \mathrm{~g} \mathrm{~L}^{-1}$, and agar (Kasvi) $15 \mathrm{~g} \mathrm{~L}^{-1}$ ) supplemented with the same antibiotics described above, and $\mathrm{pH}$ adjusted to 5.5. For each sample, roots were placed on three plates with MEA, with 15 pieces per sample in this culture medium in total. Plates were incubated at $27^{\circ} \mathrm{C}$ in the dark. 
Table 1. Municipalities and chemical characteristics, sugarcane variety, and age of the plantation of the 16 sampled points for isolation of dark septate endophytes in the sugarcane producing region of Quatá, São Paulo, Brazil.

\begin{tabular}{|c|c|c|c|c|c|c|c|c|c|c|c|c|}
\hline Municipality & $\mathrm{pH}$ & $\begin{array}{c}\mathrm{OM} \\
\mathrm{g} \mathrm{dm}^{-3}\end{array}$ & $\begin{array}{l}\text { P-resin } \\
\mathrm{mg} \mathrm{dm}^{-3}\end{array}$ & $\mathbf{K}$ & $\mathrm{Ca}$ & $\underset{\mathrm{mr}}{\mathrm{Mg}}$ & $\begin{array}{l}\mathrm{H}+\mathrm{Al} \\
\mathrm{m}^{-3}\end{array}$ & Al & СТC & $\begin{array}{l}\text { Sampled } \\
\text { Point }\end{array}$ & $\begin{array}{l}\text { Sugarcane } \\
\text { Variety }\end{array}$ & $\begin{array}{c}\text { Plantation } \\
\text { Age }\end{array}$ \\
\hline $\begin{array}{c}\text { João } \\
\text { Ramalho }\end{array}$ & 4.66 & 10.4 & 5.2 & 0.98 & 9.60 & 4.80 & 16.8 & 0.6 & 32.2 & $\begin{array}{l}1 \\
2 \\
4\end{array}$ & $\begin{array}{c}\text { RB867515 } \\
\text { RB966928 } \\
\text { RB92579 }\end{array}$ & $\begin{array}{l}\text { 1st ratoon } \\
1 \text { st ratoon } \\
1 \text { st ratoon }\end{array}$ \\
\hline $\begin{array}{l}\text { Paraguaçu } \\
\text { Paulista }\end{array}$ & 5.43 & 5.0 & 10.5 & 1.30 & 15.17 & 5.17 & 14.0 & 0.5 & 35.5 & 3 & RB867515 & 1st ratoon \\
\hline $\begin{array}{l}\text { Paraguaçu } \\
\text { Paulista }\end{array}$ & 5.45 & 10.2 & 16.4 & 2.37 & 17.00 & 6.18 & 14.8 & 0.0 & 40.4 & 11 & RB92579 & 1st ratoon \\
\hline Quatá & 5.58 & 6.1 & 7.0 & 0.96 & 14.31 & 5.92 & 14.5 & 0.9 & 35.8 & $\begin{array}{c}6 \\
9 \\
12 \\
16\end{array}$ & $\begin{array}{l}\mathrm{CE} 2 * \\
\mathrm{CE} 4 \text { * } \\
\mathrm{CE} 1 \text { * } \\
\mathrm{CE} 3 \text { * }\end{array}$ & $\begin{array}{l}\text { Plant-cane } \\
\text { Plant-cane } \\
\text { Plant-cane } \\
\text { Plant-cane }\end{array}$ \\
\hline Quatá & 5.70 & 5.0 & 3.0 & 0.53 & 10.67 & 4.67 & 11.0 & 0.0 & 27.3 & $\begin{array}{c}8 \\
10 \\
13\end{array}$ & $\begin{array}{c}\text { RB867515 } \\
\text { RB92579 } \\
\text { RB966928 }\end{array}$ & $\begin{array}{l}\text { 1st ratoon } \\
1 \text { st ratoon } \\
1 \text { st ratoon }\end{array}$ \\
\hline Quatá & 6.08 & 12.9 & 15.9 & 1.42 & 17.35 & 5.71 & 12.1 & 0.0 & 36.6 & 15 & RB92579 & 1st ratoon \\
\hline Quatá & 6.20 & 10.5 & 22.2 & 2.63 & 18.50 & 7.33 & 10.8 & 0.0 & 39.3 & 5 & RB867515 & Plant-cane \\
\hline Quatá & 6.20 & 17.0 & 43.5 & 3.55 & 19.25 & 6.75 & 13.2 & 0.0 & 42.7 & 7 & RB966928 & 1st ratoon \\
\hline Quatá & 6.21 & 5.3 & 20.6 & 1.54 & 18.00 & 5.93 & 11.2 & 0.0 & 36.8 & 14 & RB966928 & 1st ratoon \\
\hline
\end{tabular}

$\mathrm{pH}$ : hydrogenionic potential in $\mathrm{CaCl}_{2}$; OM: organic matter; P-resin: phosphorus evaluated by the resin method; CTC: cationic exchange capacity. Data provided by Zilor-Açucareira Quatá $\mathrm{S} / \mathrm{A} .{ }^{*} \mathrm{CE}$ : energy cane. CE1, CE2, CE3, and CE4 represent not commercialized sugarcane varieties. 
Fungal colonies grown from the ends of the root segments were transferred to new Petri dishes containing fresh MEA and kept under equal incubation conditions. Light-colored colonies were discarded, and only brown, gray, and black colonies were kept as they corresponded with the criteria of color differentiation proposed for DSE [1,4].

Roots not used for isolation of endophytes were colored following typical methodologies employed for observation of arbuscular mycorrhizal fungi compiled by Novais et al. [37]. Processed roots were observed in the stereoscopic microscope and colonized segments were mounted in microscopy slides for observation in the optic microscope.

\subsection{Identification of the Isolated Dark Septate Endophytic Fungi}

Discs of $7 \mathrm{~mm}$ were removed from the edges of actively growing colonies and used for DNA extraction. Each mycelial disc was transferred to a $0.5 \mathrm{~mL}$ microcentrifuge tube, containing sterilized glass beads (Sigma) $(\leq 106 \mu \mathrm{m})$ and $200 \mu \mathrm{L}$ of PrepMan ${ }^{\circledR}$ Sample Preparation Reagent (Applied Biosystems $^{\mathrm{TM}}$, Foster City, CA, USA). Sterile pestles were used to macerate the mycelium. Next, as suggested in the protocol of the manufacturer, samples were incubated at $95^{\circ} \mathrm{C}$ for $10 \mathrm{~min}$ and cooled for $2 \mathrm{~min}$ at room temperature. Subsequently, centrifugation was carried out for $10 \mathrm{~min}$ at $13,000 \mathrm{rpm}$. The supernatant containing the extracted DNA was carefully pipetted and transferred to a new microcentrifuge tube, which was kept in a freezer at $-20^{\circ} \mathrm{C}$.

The internal transcribed spacer (ITS) of the ribosomal DNA and the large subunit (LSU) of the gene $28 \mathrm{~S}$ were amplified through polymerase chain reactions (PCRs) using the primers ITS1F and ITS4 [38], and LROR [39] and LR5 [40], respectively. The PCR program for ITS consisted of initial denaturation at $95{ }^{\circ} \mathrm{C}$ for $2 \mathrm{~min}$; 35 cycles of denaturation $\left(95^{\circ} \mathrm{C}\right.$ for $\left.45 \mathrm{~s}\right)$, annealing $\left(52{ }^{\circ} \mathrm{C}\right.$ for $45 \mathrm{~s}$ ), and extension $\left(72{ }^{\circ} \mathrm{C}\right.$ for $120 \mathrm{~s}$ ); and final extension at $72{ }^{\circ} \mathrm{C}$ for $5 \mathrm{~min}$. For LSU, the PCR program consisted of initial denaturation at $94^{\circ} \mathrm{C}$ for $2 \mathrm{~min} ; 35$ cycles of denaturation $\left(94^{\circ} \mathrm{C}\right.$ for $\left.60 \mathrm{~s}\right)$, annealing $\left(50{ }^{\circ} \mathrm{C}\right.$ for $\left.30 \mathrm{~s}\right)$, and extension $\left(72{ }^{\circ} \mathrm{C}\right.$ for $\left.90 \mathrm{~s}\right)$; and final extension at $72{ }^{\circ} \mathrm{C}$ for $10 \mathrm{~min}$.

Additionally, the primers EF1-728F [41] and EF2Rd [42] were used to amplify part of the translation elongation factor $1 \alpha$ region (TEF). Part of the actin (ACT) and $\beta$-tubulin (TUB) genes were also amplified using the primers ACT-512F [41] and ACT2Rd [42], and CYLTUB1F [42] and Bt2b [43], respectively. The PCR program for the TEF, ACT, and TUB regions consisted of initial denaturation at $94{ }^{\circ} \mathrm{C}$ for $5 \mathrm{~min}$; 40 cycles of denaturation $\left(94^{\circ} \mathrm{C}\right.$ for $\left.45 \mathrm{~s}\right)$, annealing $\left(52^{\circ} \mathrm{C}\right.$ for $\left.30 \mathrm{~s}\right)$, and extension $\left(72{ }^{\circ} \mathrm{C}\right.$ for $120 \mathrm{~s} \mathrm{TEF} ; 72^{\circ} \mathrm{C}$ for $90 \mathrm{~s} \mathrm{ACT}$ and TUB); and final extension at $72{ }^{\circ} \mathrm{C}$ for $6 \mathrm{~min}$ [44].

The PCR mixture contained 0.2 mM of dNTP, 1X Colorless Gotaq Flexi Buffer (Promega, Madison, WI, USA), $0.6 \mathrm{U}$ of GoTaq ${ }^{\circledR}$ Flexi DNA polymerase (Promega), $0.2 \mu \mathrm{M}$ of each primer, $2 \mu \mathrm{L}$ of genomic DNA, and 3 or $2 \mathrm{mM}$ of $\mathrm{MgCl}_{2}$, for all the five regions (ITS, LSU, TEF, ACT, TUB). The mixture of each reaction was completed with ultrapure PCR water to a final volume of $25 \mu \mathrm{L}$.

The PCR products were purified using the enzymes Exonuclease I $\left(20 \mathrm{U} \mathrm{L}^{-1}\right)$ and FastAP Thermosensitive Alkaline Phosphatase $\left(1 \mathrm{U} \mathrm{LL}^{-1}\right)$. Sequencing reactions were performed in a 3500 genetic analyzer using the BigDye ${ }^{\mathrm{TM}}$ Terminator Cycle Sequencing Kit v.3.1 (Applied Biosystems ${ }^{\mathrm{TM}}$ ). Sequences were compared with already deposited sequences in the GenBank ${ }^{\circledR}$ of the National Center for Biotechnology Information (NCBI) of the U.S. National Library of Medicine using BLAST 2.8.0 (Nucleotide Basic Local Alignment Search Tool) $[45,46]$. The BLAST search for ITS and LSU considered a similarity cutoff of $95 \%$ and excluded sequences from models (XM/XP), as well as uncultured and environmental samples. An additional BLAST search, with $85 \%$ similarity cutoff, was conducted considering only deposited sequences from type material. The BLAST search for TEF, ACT, and TUB considered only the sequences with the highest similarity identity.

The sequences of the isolated fungi were aligned with similar ones retrieved from GeneBank using ClustalW in MEGA X [47]. ITS and LSU sequences of type material regarding the fungal species Peziza oliviae J. L. Frank and Peziza tarembergensis Moyne, Stöckli, C. Page \& Van Vooren were included as outgroup references. 
Phylogenetic analyses were conducted in MEGA X [47]. Phylogenetic trees were inferred by the maximum likelihood method (ML) and the general time reversible (GTR) model [48]. Initial trees for the heuristic search were obtained automatically by applying the neighbor-joining and BioNJ algorithms to a matrix of pairwise distances estimated using the maximum composite likelihood (MCL) approach and selection of the topology with the highest log likelihood value. The support of the branches was verified through a bootstrap test with 5000 replicates.

The names of the species were checked for synonymies and current nomenclature in the taxonomic bases MycoBank [49] and Index Fungorum [50]. Molecular identification was complemented by morphological characters, for which microscopy slides were mounted for each isolate using the micro-culture technique [51], followed by observation in an optical microscope.

The isolated fungi were preserved through Castellani's method and cryopreservation. In both cases, $5 \mathrm{~cm}$ discs were withdrawn from colonies growing in MEA. In the case of the Castellani's method, discs were transferred to $2 \mathrm{~mL}$ microtubes and covered with sterilized distilled water, and then kept refrigerated at $4{ }^{\circ} \mathrm{C}$. For cryopreservation, discs were transferred to $2 \mathrm{~mL}$ cryogenic tubes containing a sterilized solution of malt extract (Sigma-Aldrich) and glycerin (Isofar) and kept at a temperature of $-80^{\circ} \mathrm{C}$. Isolates were deposited at the Fungal Collection of the Johanna Döbereiner Biological Resources Center (CRB-JD), which belongs to Embrapa Agrobiology, Brazil. Sequences of the isolated fungi were deposited in the NCBI database (Table S1).

\section{Results/Discussion}

\subsection{Isolates of Dark Septate Endophytes}

Microscopical observations of the roots allowed verifying the occurrence of colonization by DSE in the sampled sugarcane plants (Figure 2). Typical structures of this symbiosis, such as melanized and hyaline (under formation) microsclerotia, as well as septate hyphae, were verified within the roots.

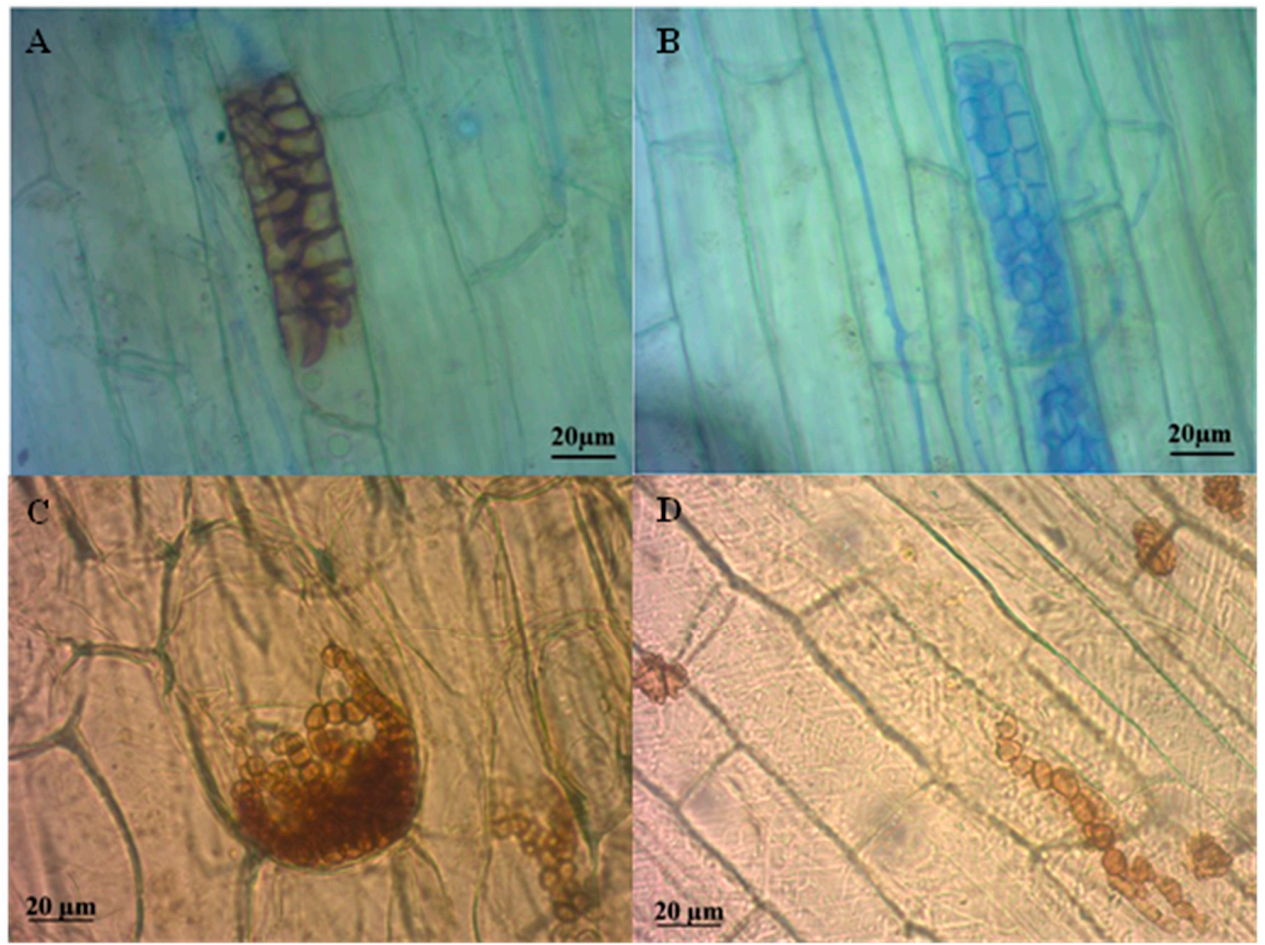

Figure 2. Colonization of sugarcane roots by dark septate endophytes in plants from the sugarcane producing region of Quatá, São Paulo, Brazil. Black arrows indicate melanized (A), hyaline colored with methyl blue (B), and forming (C,D) microsclerotia. 
A total of 63 colonies of root endophytic fungi were isolated from the 16 sampled points. From these, 26 colonies were from the variety RB966928; 17 from energy cane (CE1: seven isolates; CE2: three isolates; CE3: two isolates; CE4: five isolates); 15 from RB867515; and 5 from RB92579 (Tables 1 and 2). However, only 16 out of the total number of isolates $(25 \%)$ had dark-colored colonies when grown in MEA and incubated in the dark at a temperature of $27^{\circ} \mathrm{C}$, indicating the possibility of being DSE [1]. Grouping based on the color of the colonies may exclude DSE fungi, but there are still no well-established criteria for the differentiation of fungi that belong to this group [10]. In general, the symbiosis with DSE fungi seems to be common among sugarcane varieties. The largest number of dark colonies was obtained from the roots of the varieties RB966928 and RB867515, with six and five isolates, respectively, followed by the varieties CE3 and RB92579, with three and two isolates, respectively. The macromorphology of the colonies of these 16 fungal isolates is presented in Figure S1.

Table 2. Sugarcane variety, age of the plantation, and number of isolates (total and dark-colored). Plants grown in the sugarcane producing region of Quatá, São Paulo, Brazil.

\begin{tabular}{cccccc}
\hline \multirow{2}{*}{ Sugarcane Variety } & Plantation Age & Sampled Point & \multicolumn{3}{c}{ Isolated Colonies } \\
\cline { 3 - 5 } & & & Total & Dark & Code Assigned * \\
\hline \multirow{2}{*}{ RB867515 } & 1st ratoon & 1 & 3 & 2 & A111, A112 \\
& 1st ratoon & 3 & 4 & 0 & - \\
& Plant-cane & 5 & 2 & 0 & A113-A115 \\
& 1st ratoon & 8 & 6 & 3 & - \\
RB92579 & 1st ratoon & 4 & 0 & 0 & A116 \\
& 1st ratoon & 10 & 0 & 0 & A117 \\
& 1st ratoon & 11 & 3 & 1 & - \\
& 1st ratoon & 15 & 2 & 1 & A118-A121 \\
RB966928 & 1st ratoon & 2 & 12 & 0 & - \\
& 1st ratoon & 7 & 8 & 4 & A122, A123 \\
\hline CE1 & 1st ratoon & 13 & 2 & 0 & - \\
CE2 & 1st ratoon & 14 & 4 & 2 & - \\
CE3 & Plant-cane & 12 & 2 & 0 & A124-A126 \\
CE4 & Plant-cane & 6 & 7 & 0 & - \\
\hline
\end{tabular}

* Fungal Collection of the Johanna Döbereiner Biological Resources Center.

For nine of the sampled points, no isolates with DSE appearance were obtained (Table 2). Limitations related to the selective character of the culture-dependent method used may have underestimated the diversity of DSE at these sampling points. On the other hand, the sampling of only one clump at each point may also have negatively influenced the number of isolates. Finally, the age of the plants should also be considered as a relevant factor when addressing this aspect. Most of the samples were taken from plants growing as the first ratoon (Table 2). In the samples taken from plant cane, only those of the CE3 variety resulted in DSE isolation. Claassens et al. [32] evaluated the dynamics of DSE colonization in sugarcane plants throughout the crop cycle and detected a decrease in root occupation by DSE in the second ratoon compared with the first. According to Lin et al. [52], there is a higher expression of plant proteins associated with stress/defense mechanisms in the ratoon phase. Thus, considering the large number of reports related to the importance of DSE in increasing the tolerance of plants to stress conditions [15,53], it could be inferred that, in sugarcane, ratoon plants might be more dependent on the DSE symbiosis.

All the DSE isolates formed septate and melanized hyphae and were grouped by similar micromorphological characteristics. Isolates A111, A113, A115, and A124-A126 presented colonies dark brown to black with a diameter growth rate of $0.3-0.5 \mathrm{~mm} /$ day $(\bar{x}=0.4 \pm 0.1 \mathrm{~mm} /$ day, $n=12)$ in the first week in MEA at $28^{\circ} \mathrm{C}$ (Figure S1). Brown, macronematous conidiophores arising singly or in groups of up to four on stromata were observed, mostly with a stipe and apical conidial head unbranched or branched (Figure 3). These conidiophores were 5.6-12.0 $\mu \mathrm{m}$ wide at the base $(\bar{x}=$ 
$8.3 \pm 2 \mu \mathrm{m}, n=30)$ and $40-184 \mu \mathrm{m}$ long $(\overline{\mathrm{x}}=108 \pm 42 \mu \mathrm{m}, n=30)$. Conidial heads had a diameter of 33-90 $\mu \mathrm{m}(\overline{\mathrm{x}}=60 \pm 13 \mu \mathrm{m}, n=30)$. Micronematous conidiophores arising directly from hyphae were also observed. Conidiogenous cells were monoblastic or polyblastic, ellipsoidal to spherical, and formed directly on stipes or branches. These cells were 4.0-8.3 $\mu$ m wide $(\bar{x}=5.6 \pm 0.9 \mu \mathrm{m}, n=20)$ and 5.0-9.3 $\mu \mathrm{m}$ long $(\overline{\mathrm{x}}=6.3 \pm 0.9 \mu \mathrm{m}, n=20)$. Conidiophores supported $1-13$ spherical to ellipsoidal conidia born singly or in short chains over conidiogenous cells. These conidia were 8.3-16.8 $\mu \mathrm{m}$ $(\overline{\mathrm{x}}=13.1 \pm 2.0 \mu \mathrm{m}, n=20)$ in the narrowest diameter and 9.3-17.6 $\mu \mathrm{m}(\overline{\mathrm{x}}=13.9 \pm 2.1 \mu \mathrm{m}, n=20)$ in the widest one. They also presented coarsely echinulate ornamentations consisting of curved spines 1.0-3.3 $\mu \mathrm{m}$ long $(\overline{\mathrm{x}}=1.8 \pm 0.6 \mu \mathrm{m}, n=20)$ adhered close to each other.

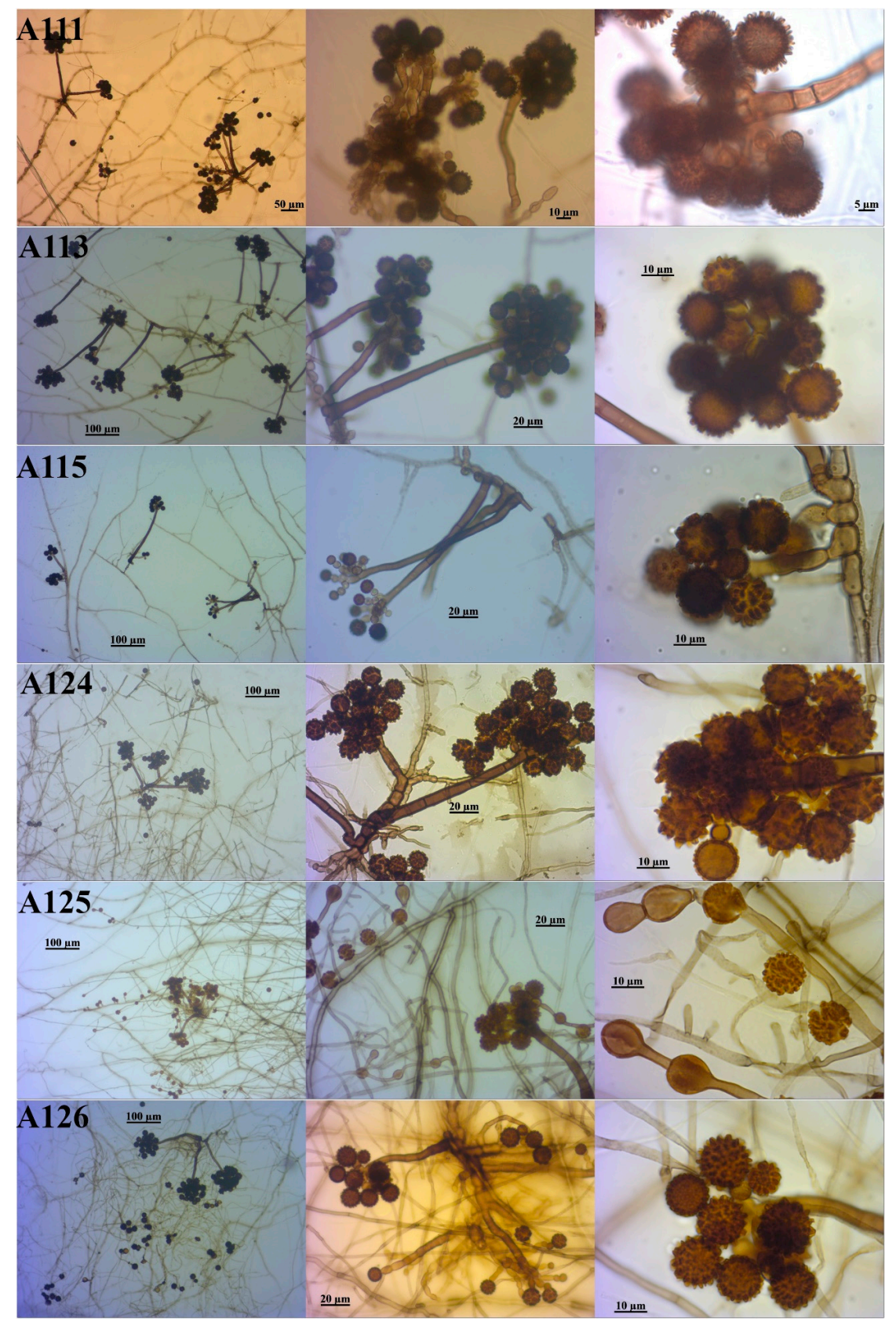

Figure 3. Micromorphology of hyphae and other fungal structures of DSE fungi (A111, A113, A115, A124-A126) grown in malt extract agar after isolation from sugarcane roots sampled in the Quatá region, São Paulo, Brazil. 
Isolate A112 presented colonies varying from brown to dark brown on the top, and white to grey on their reverse when grown in MEA at $28^{\circ} \mathrm{C}$ (Figure S1). Conidiophores were flexuous, septate, and geniculate, and 3.2-4.8 $\mu \mathrm{m}$ wide at the base $(\overline{\mathrm{x}}=4.0 \pm 0.5 \mu \mathrm{m}, n=8)$ and up to 100-318 $\mu \mathrm{m}$ long $(\bar{x}=194 \pm 97, n=6)$ (Figure 4). Conidia were hyaline, ellipsoidal, often curved or lunate, rounded at the ends or sometimes tapering slightly towards the base, and produced in sympodial succession. These conidia were $50-82 \mu \mathrm{m}$ wide $(\overline{\mathrm{x}}=69 \pm 7.5, n=20)$ and $125-286 \mu \mathrm{m}$ long $(\overline{\mathrm{x}}=179 \pm 35, n=20)$, usually with four septa $(\overline{\mathrm{x}}=3.9 \pm 0.3, n=20)$ and a smooth wall and protuberant hilum.
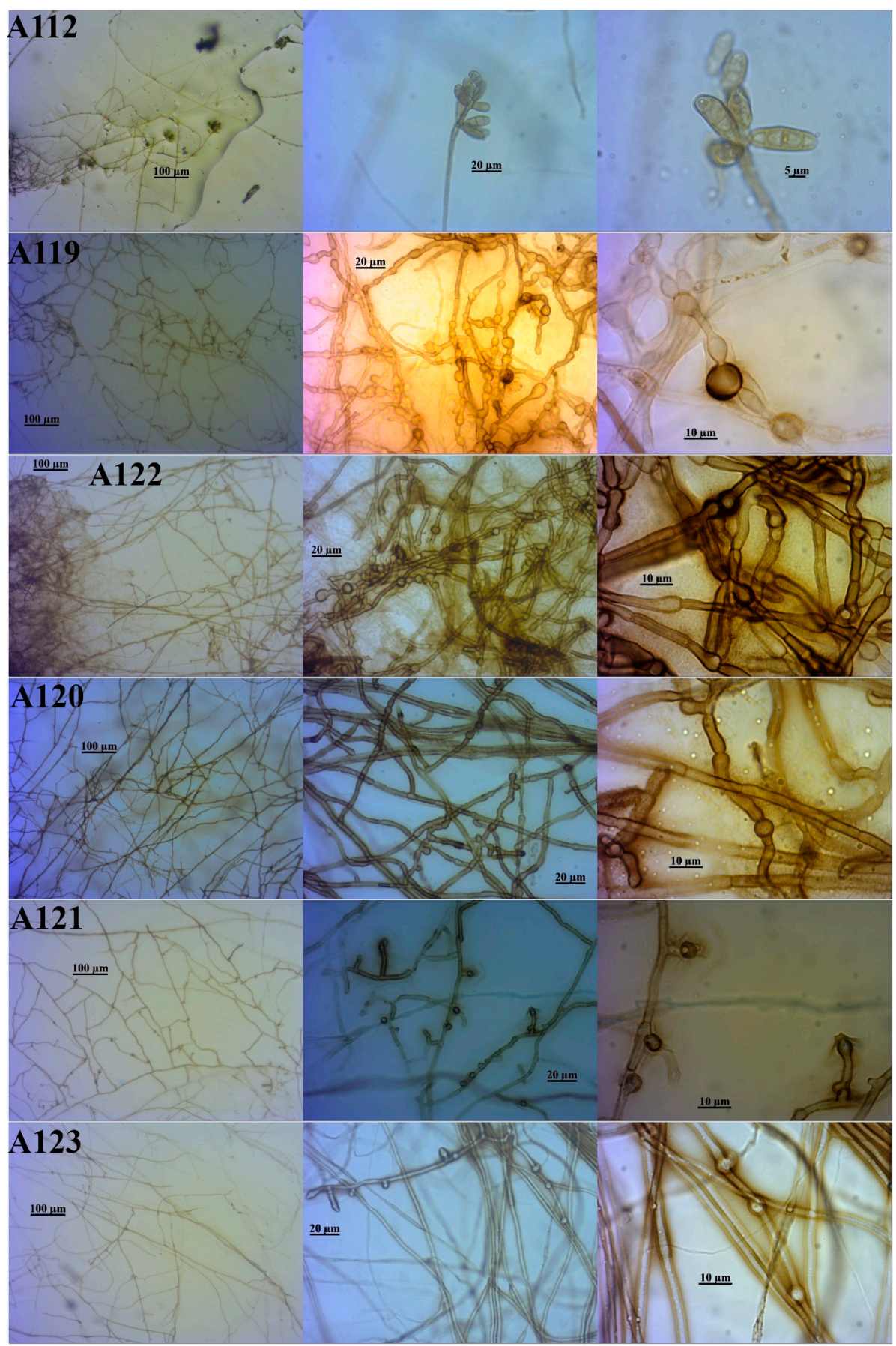

Figure 4. Micromorphology of hyphae and other fungal structures of DSE fungi (A112, A119-A123) grown in malt extract agar after isolation from sugarcane roots sampled in the Quatá region, São Paulo, Brazil. 
Isolates A119-A123 had colonies dark brown to black, dense, and irregular, with undulate edges and a mean diameter growth rate of $0.9 \pm 0.03 \mathrm{~mm} /$ day in the first week when grown in MEA at $28^{\circ} \mathrm{C}$ (Figure S1). Chlamydospores were hyaline to dark brown, observed frequently intercalary in hyphae sole, but also in branched chains, with thickened and darkened walls, constricted near the septa, variable in shape from globose or cylindrical to pyriform. They were $4-10 \mu \mathrm{m}$ wide $(\bar{x}=5.5 \pm 1.6 \mu \mathrm{m}$, $n=25)$ and $4-11 \mu \mathrm{m}$ long $(\overline{\mathrm{x}}=6.2 \pm 1.6 \mu \mathrm{m}, n=25)$ (Figure 4). Sexual morph was undetermined.

Isolate A118 formed dark brown to black colonies, with circular and entire edges when grown in MEA at $28^{\circ} \mathrm{C}$ (Figure S1). Sporulation was not observed. The mycelium was septate and smooth, and hyphae were $2.3-5.0 \mu \mathrm{m}$ wide $(\bar{x}=3.6 \pm 0.7 \mu \mathrm{m}, n=20)$. These were hyaline when new and became light brown to dark brown with age, commonly forming straight lines that formed well-defined angles (Figure 5). Some of the hyphae had small tips of thickened walls, arrow or peg-shaped, from which new mycelia sprouted.

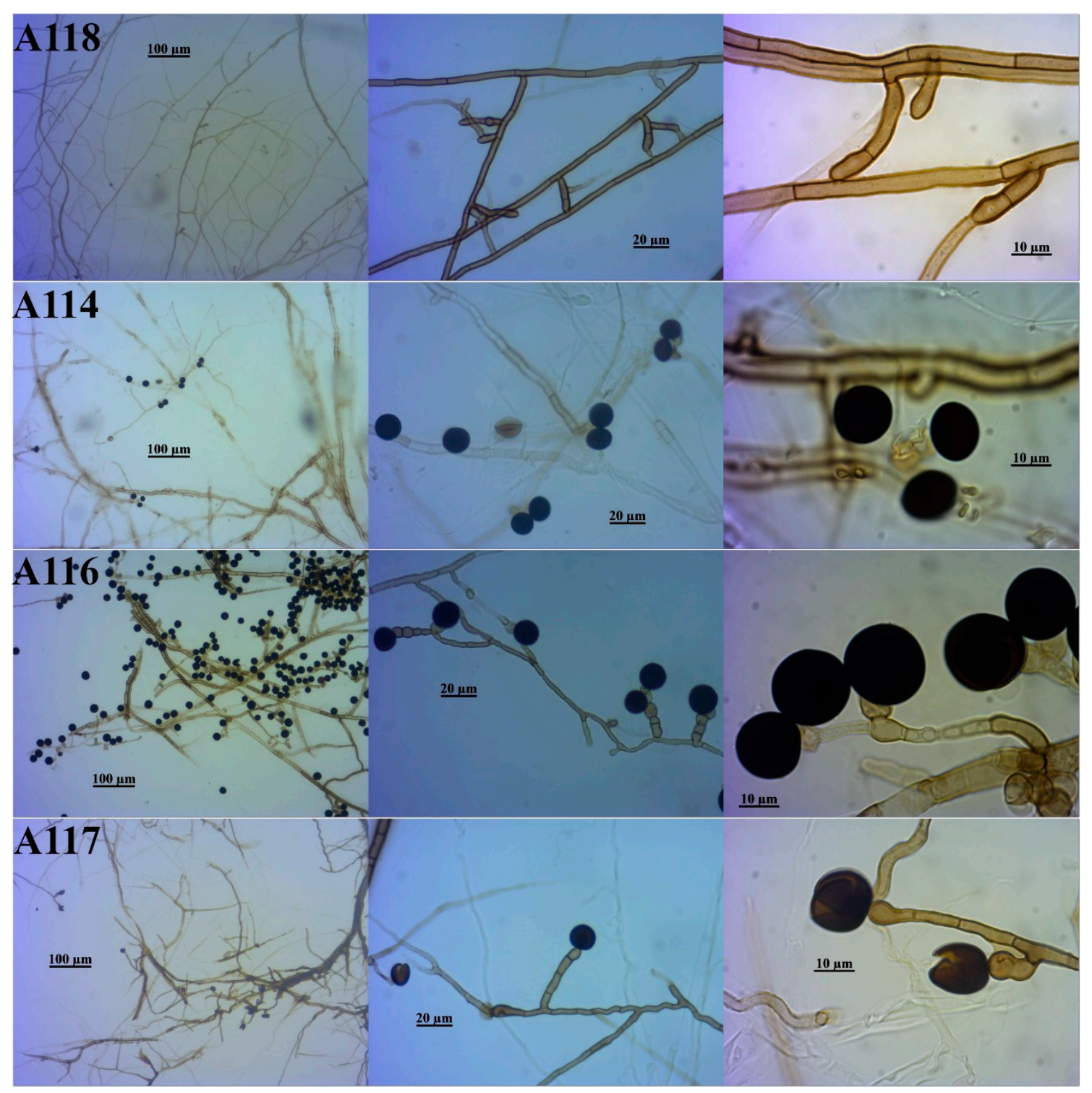

Figure 5. Micromorphology of hyphae and other fungal structures of DSE fungi (A114, A116-A118) grown in malt extract agar after isolation from sugarcane roots sampled in the Quatá region, São Paulo, Brazil. 
Isolates A114, A116, and A117 presented dark grey to black colonies, with margin and form varying among isolates, when grown in MEA at $28^{\circ} \mathrm{C}$ (Figure S1). Hyphae were hyaline to dark brown, smooth, septate, and 2.0-7.0 $\mu \mathrm{m}$ wide $(\overline{\mathrm{x}}=4.1 \pm 1.3 \mu \mathrm{m}, n=21)$. Brown conidiophores, unbranched or branched, arose directly from the hyphae (Figure 5). The conidiogenous cells were monoblastic, inflated, and oblong, and had a black, spherical to ellipsoidal single conidium at their apex, which was 9.7-20.0 $\mu \mathrm{m}$ in the narrowest diameter $(\overline{\mathrm{x}}=14.5 \pm 3.0 \mu \mathrm{m}, n=21)$ and $11.7-20.7 \mu \mathrm{m}$ in the widest diameter $(\overline{\mathrm{x}}=15.6 \pm 2.7, n=21)$.

\subsection{Identification of the DSE Isolates}

Sequences of the ITS and LSU regions were successfully obtained from 14 and 11 of the isolates, respectively. A combination of micromorphology and sequence analysis allowed the identification of all the DSE isolates, which were distributed in six taxonomic groups (Figures 6 and 7; Table 3).

All the isolates were classified as belonging to the phylum Ascomycota, differentiating into three classes and five families, and at least five genera (Table 3). This pattern of the predominance of ascomycetous is common within fungal root endophytic communities, as confirmed by previous works $[10,24,30,54]$. Particularly, DSE fungi, although constituting a polyphyletic group, all belong to this division [2]. The class Dothideomycetes, with 12 isolates, was the best represented, followed by Sordariomycetes and Leotiomycetes with three and one isolate, respectively.

The identified orders-Helotiales, Pleosporales, and Xylariales-comprise species commonly recognized as DSE [1,5]. Among these orders, Pleosporales (class Dothideomycetes) presented the highest number of isolates (75\%). Although this represents the first study to report DSE diversity in sugarcane, previous research addressing the diversity of these fungi associated with other plants has reported a similar pattern regarding the dominance of pleosporalean species or genera. Rothen et al. [24], when studying the DSE diversity associated with two phases of the soybean crop cycle, identified $91 \%$ of the isolates as members of the order Pleosporales. In the Brazilian Atlantic Forest, Bonfim et al. [8] identified $43 \%$ of the DSE operational taxonomic units (OTUs) as belonging to this order. Knapp et al. [10] reported that 7 of the 14 verified DSE groups associated with grasses in the Great Hungarian Plain were representatives of the order Pleosporales. In the northwest region of the Venezuelan semiarid, Loro et al. [55] highlighted the dominance of the DSE genera Phoma and Cochliobolus, both belonging to the order Pleosporales, in the community of endophytic fungi.

The phylogenetic trees of the ITS and LSU sequences inferred by the ML method and GTR model (Figures 6 and 7) indicate that the isolates A111, A113, A115, A124, A125, and A126 belong to the genus Periconia. The ITS tree (Figure 6) shows that, in $99 \%$ of the replicate trees in the bootstrap test, these isolates clustered together with strains of the species Periconia macrospinosa. In the LSU tree (Figure 7), these isolates clustered too with other species of the genus Periconia, as P. circinata and P. ignaria. While $92 \%$ of the bootstrap replicates supported this last grouping, in $43 \%$ of the bootstrap replicates, these isolates remained clustered together with P. macrospinosa. The conidial morphology of the isolates allowed their identification as P. macrospinosa [56]. Grünig et al. [1] refers to P. macrospinosa as one of the most abundant DSE species. Several studies involving the diversity of root-associated fungi (RAF) have verified the occurrence of species of the genus, indicating its worldwide distribution. Herrera et al. [57] reported the occurrence of Periconia sp. among the best represented OTUs within the RAF community of Eustachys petraea plants sampled on an island off the Honduran coast. In prairies under an annual burning regime in the Midwestern United States, Mandyam et al. [12] detected the species P. macrospinosa as the most frequently isolated root endophyte. In the Great Hungarian Plain, Knapp et al. [10] reported the occurrence of P. macrospinosa associated with common grasses of this ecosystem. 


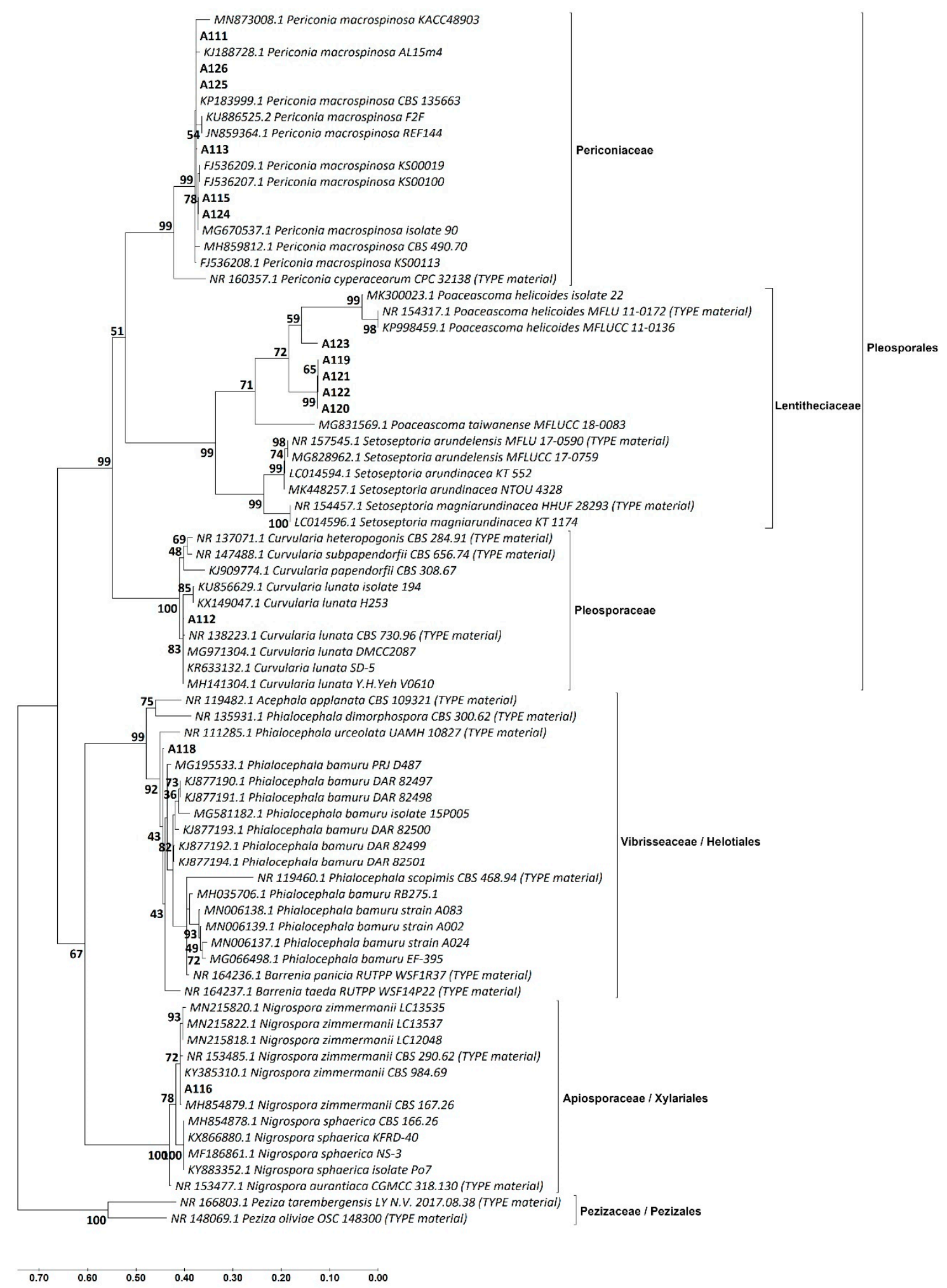

Figure 6. Phylogenetic tree of the internal transcribed spacer (ITS) region of dark septate endophytic fungi isolated from sugarcane roots (in bold) and similar sequences from GenBank. Two Peziza species were added as outgroup references. Tree inferred by the maximum likelihood method and general time reversible model, with the highest log likelihood $(-10,729.97)$. Branch lengths analysis involved 75 nucleotide sequences of a total of 2398 positions in the dataset. Numbers next to the branches indicate the percentage of replicate trees in which the associated taxa clustered together (5000 replicates bootstrap test). 


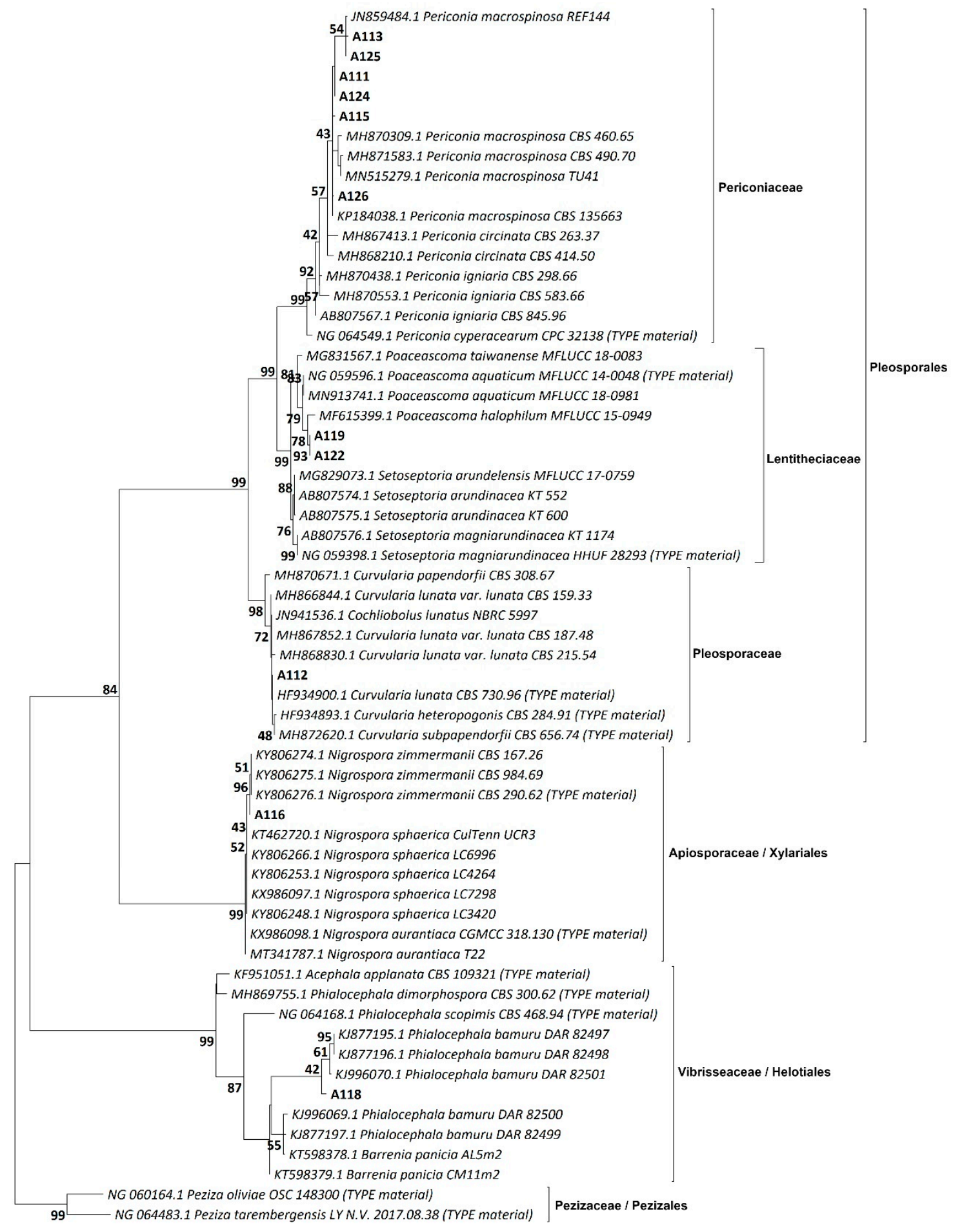

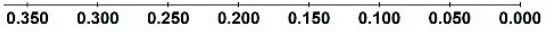

Figure 7. Phylogenetic tree of the large subunit (LSU) region of dark septate endophytic fungi isolated from sugarcane roots (in bold) and similar sequences from GenBank. Two Peziza species were added as outgroup references. Tree inferred by the maximum likelihood method and general time reversible model with the highest log likelihood (-8253.44). Branch lengths analysis involved 61 nucleotide sequences of a total of 1889 positions in dataset. Numbers next to the branches indicate the percentage of replicate trees in which the associated taxa clustered together (5000 replicates bootstrap test). 
Table 3. Identification of the dark septate endophytic fungi isolated from roots of sugarcane sampled in the producing region of Quatá, São Paulo, Brazil. ITS, internal transcribed spacer; LSU, large subunit; BLAST, Nucleotide Basic Local Alignment Search Tool.

\begin{tabular}{|c|c|c|c|c|c|c|}
\hline \multirow[t]{2}{*}{ Isolate Code * } & \multirow{2}{*}{$\begin{array}{l}\text { Identification Based on } \\
\text { Morphological Similarity }\end{array}$} & \multicolumn{2}{|c|}{$\begin{array}{c}\text { Closest Identification Based on BLAST and ML } \\
\text { Phylogenetic Analysis of }\end{array}$} & \multicolumn{3}{|c|}{ Identification Consensus of This Study } \\
\hline & & ITS Sequences & LSU Sequences & Genus/Species & Family & Order \\
\hline \multicolumn{7}{|c|}{ Class Dothideomycetes } \\
\hline A111 & Periconia macrospinosa & Periconia macrospinosa & Periconia af. macrospinosa & Periconia macrospinosa & & \multirow{12}{*}{ Pleosporales } \\
\hline A113 & Periconia macrospinosa & Periconia macrospinosa & Periconia af. macrospinosa & Periconia macrospinosa & & \\
\hline A115 & Periconia macrospinosa & Periconia macrospinosa & Periconia af. macrospinosa & Periconia macrospinosa & & \\
\hline A124 & Periconia macrospinosa & Periconia macrospinosa & Periconia af. macrospinosa & Periconia macrospinosa & Periconiaceae & \\
\hline A125 & Periconia macrospinosa & Periconia macrospinosa & Periconia af. macrospinosa & Periconia macrospinosa & & \\
\hline A126 & Periconia macrospinosa & Periconia macrospinosa & Periconia af. macrospinosa & Periconia macrospinosa & & \\
\hline A112 & Curvularia sp. & Curvularia lunata & Curvularia af. lunata & Curvularia lunata & Pleosporaceae & \\
\hline A119 & Not identified & Poaceascoma sp. & Poaceascoma af. halophilum & Poaceascoma sp. & \multirow{5}{*}{ Lentitheciaceae } & \\
\hline A122 & Not identified & Poaceascoma sp. & Poaceascoma af. halophilum & Poaceascoma sp. & & \\
\hline A120 & Not identified & Poaceascoma sp. & Not identified & Poaceascoma sp. & & \\
\hline A121 & Not identified & Poaceascoma sp. & Not identified & Poaceascoma sp. & & \\
\hline A123 & Not identified & Poaceascoma sp. & Not identified & Poaceascoma sp. & & \\
\hline \multirow[t]{2}{*}{ A118 } & Phialocephala sp. & Phialocephala sp. & $\begin{array}{l}\text { Class Leotiomycetes } \\
\text { Phialocephala af. bamuru }\end{array}$ & Phialocephala sp. & Vibrisseaceae & Helotiales \\
\hline & & \multirow{4}{*}{$\begin{array}{l}\text { Not identified } \\
\text { Nigrospora } \\
\text { zimmermanii } \\
\text { Not identified }\end{array}$} & Class Sordariomycetes & \multirow{4}{*}{$\begin{array}{l}\text { Nigrospora sp. } \\
\text { Nigrospora } \\
\text { zimmermanii } \\
\text { Nigrospora sp. }\end{array}$} & & \multirow{4}{*}{ Xylariales } \\
\hline A114 & Nigrospora sp. & & Not identified & & Apiosporaceae & \\
\hline A116 & Nigrospora sp. & & Nigrospora zimmermanii & & Apiosporaceae & \\
\hline A117 & Nigrospora sp. & & Not identified & & Apiosporaceae & \\
\hline
\end{tabular}

*: Fungal Collection of the Johanna Döbereiner Biological Resources Center. ML: maximum likelihood method. 
The isolate A112 was identified according to the morphology of its conidia as belonging to the genus Curvularia $[58,59]$. This isolate clustered together with Curvularia lunata in $83 \%$ of the bootstrap replicates of the ITS tree (Figure 6). However, in the LSU tree, it formed a cluster with strains of Curvularia lunata and Curvularia heteropogonis, and type material sequences of Curvularia subpapendorfii in $72 \%$ of the bootstraps. Although many species within the genera Curvularia are considered to be saprophytic or pathogenic [60], there are also several reports of species occurring as grass and tree endophytes $[8,10,12,55]$. From the biotechnological point of view, the importance of this genus has been highlighted [61]. An extract from a grass endophytic isolate of $C$. lunata was proved to act as an inhibitor of phytopathogenic fungi and bacteria [62].

When it comes to the relationship of the species of this genus with sugarcane, previous research has confirmed Curvularia spp. as causing agents of foliar diseases in this crop. Species such as Curvularia sengalensis and C. lunata, for instance, are known to cause seedling foliage blight and leaf spot [63,64]. A recent study, however, indicated the occurrence of at least 22 Curvularia species, including C. lunata, associated with sugarcane diseased tissues of roots and leaves [65]. On the other hand, the genera Curvularia has been reported as part of the community of fungi associated with healthy sugarcane roots, especially in the rhizosphere [30].

The isolates A119-A123 could not be identified by their morphology. In the ITS tree, both, and particularly the isolate A123, clustered in a clade with Poaceascoma helicoides, which was supported by $72 \%$ of the bootstrap replicates. Isolates A119-A122 separated from the isolate A123 in 100\% of bootstraps. For the LSU tree, only the sequences of the isolates A119 and A122 were obtained. These isolates confirmed proximity to each other in $93 \%$ of the bootstraps, while in $78 \%$ of the bootstraps, they formed a clade with Poaceascoma halophilum. In both the ITS and LSU trees, the genus Poaceascoma separated from the genus Setoseptoria in $99 \%$ of the bootstraps. The reports of Poaceascoma species associated with sugarcane are scarce, and according to Raza et al. [65], their study was the first to document the occurrence of this genus associated with this crop. In correspondence with this, previous results regarding the diversity of fungi in sugarcane tissues or rhizospheric soil in Brazil have not reported the presence of this genus [30].

The isolate A118 did not produce spores in culture, which made its morphological identification difficult. However, the arrow or peg-shaped thickened wall tips of the mycelium are similar to microsclerotia previously verified for Phialocephala nodosa [66] and to pegs or appressoria in Phialocephala bamuru [67]. This isolate was grouped in the ITS and LSU trees, with $92 \%$ and $87 \%$ of bootstrap replicates, respectively, in clades with strains of Phialocephala bamuru and type material of Phialocephala scopimis and Phialocephala urceolata (only ITS tree). Barrenia panici and Barrenia taeda type material also clustered in these clades, but currently, these species are incertae sedis under the class Leotiomycetes of the Helotiales order $[49,50,68]$. In both trees (ITS and LSU), these clades were clearly separated from the type material of Acephala applanata and Phialocephala dimorphospora, in $99 \%$ of the bootstrap replicates. An extensive phylogenetic analysis recently documented a simple Barrenia clade formed by unnamed isolates from diverse host plants, including grasses and sedges (ex. Saccharum sp.), as well as root and foliar endophytes of hosts within Ericaceae, Orchidaceae, and Pinaceae, among others [69]. The authors also highlighted the inclusion in this clade, not only of Barrenia species, such as B. panicia, but also of $P$. bamuru and species within other fungal genera.

The genus Phialocepha is represented by wood decaying species and some endophytic fungi, mostly isolated from temperate climate regions around the world, also including important DSE members [1,69]. Pathogens within this genus have been described as well, with P. bamuru affecting the grasses Cynodon dactylon and Pennisetum clandestinum, causing fairway patch in golf courses of Australia [67]. In terms of endophytic associations, the Phialocepha fortinii-Acephala applanata complex (PAC) stands out as one of the most common DSEs in boreal forests in North America and Europe [1,2]. Although studies regarding the occurrence of the PAC in the southern hemisphere are still scarce, research findings suggest that, even when present, it might not be a predominant DSE group in this region [1,8]. On the other hand, the genus Barrenia was recently described by Walsh et al. [68], 
who recognized its species as probable DSE fungi considering the formation of septate hyphae, their root colonizing habit, and their close phylogenetic relationship with the PAC. Overall, the identification of these genera associated with sugarcane plants, as endophytes or even pathogens, seems to be uncommon [30].

The isolates A114, A116, and A117 were identified morphologically as belonging to the genus Nigrospora, considering their typical spherical to ellipsoidal conidia to be deeply black pigmented [70]. In the present study, only sequences from the isolate A116 were obtained and used for molecular analysis. The isolate A116 formed a separate clade with strains of the species Nigrospora zimmermanii in both trees, ITS and LSU, with $72 \%$ and $96 \%$ of bootstrap, respectively. In both trees, strains of the species Nigrospora sphaerica formed a clade with A116 and Nigrospora zimmermanii, while remaining separated from the species Nigrospora aurantiaca.

The genus Nigrospora is known for its ubiquitous distribution and nutritional relationships varying from pathogenic to endophytic in a wide range of plant species [70,71]. Endophytes of Nigrospora spp. have been previously identified in roots of Moringa oleifera [72] and several tree species of the Brazilian Atlantic Forest [8]. In the Venezuelan semiarid, N. oryzae and N. sphaerica were confirmed as leaf, stem, or root endophytes of common grasses of the region [55]. On the other hand, there is also plenty of research documenting the pathogenic effect of these and other species. The leaf blight disease caused by N. sphaerica in plants of Mentha canadensis [73] and the leaf spot caused by N. oryzae in Citrullus lanatus (watermelon) can be cited as examples [74].

Reports regarding the association between S. officinarum and species of the genus Nigrospora are still scarce. However, they suggest the prevalence of pathogenic interactions. A recent study evaluated the diversity of culturable pathogenic fungi in sugarcane leaves and roots in southern China, indicating Nigrospora as one of the most frequently isolated genera, accounting for around $20 \%$ of the strains [65]. Among the species reported by the authors were N. aurantiaca, N. camelliae-sinensis, N. hainanensis, N. lacticolonia, N. pyriformis, N. sphaerica, N. zimmermanii, N. falsivesicularis, N. vesicularifera, N. saccharicola, N. sacchari-officinarum, and N. singularis. Another study, also conducted in China, reported N. sphaerica as the causing agent of leaf blight in sugarcane [75].

DNA from 13, 13, and 10 isolates was successfully amplified and sequenced for TEF, ACT, and TUB, respectively (Table S1). BLAST searches for TEF, ACT, and TUB resulted in low values of percent identity for most of the isolates (Table S2), suggesting insufficient deposit of sequences from these regions for DSE fungi in the NCBI database. Despite this, the phylogenetic trees using ACT, TEF, and TUB sequences from the fungal strains isolated in the present study and those retrieved from GenBank according to the closest BLAST results (Figures S2-S4) supported the results obtained through the phylogeny of the ITS and LSU regions. Sequences with high percent identity $(>98 \%)$ were only obtained for the ACT gene when conducting BLAST search for the isolates A111, A113, A115, and A124-A126, which were closely related to Periconia macrospinosa. For the TEF gene, this was also true when conducting the BLAST search for the isolates A112 and A116, which showed high similarity with Curvularia spp. and Nigrospora sp., respectively. Finally, for the TUB gene, the isolate A116 had $100 \%$ identity correspondence with Nigrospora zimmermanii (Table S2).

Some gene codifying regions have a better range of distinction when compared with the ITS region, currently considered the universal barcode for fungi [76]. However, their use is still restricted owing to the difficult amplification verification in some cases, as well as low availability of sequences in databases, and the limited number of species that have been sequenced and deposited [77]. For certain genera such as Aspergillus, Fusarium, Penicillium, and Trichoderma, the ITS region is most of the time insufficient for species differentiation [78], thus the use of secondary molecular markers is more common $[77,79]$. However, for DSE species, there is a greater number of studies using only the ITS region $[8,24,80]$, and the use of secondary markers is still scarce [7].

Some of the fungal species identified here have also been previously reported as decomposers of decaying Miscanthus and sugarcane plants [81]. Among these fungi are P. macrospinosa and other unidentified species belonging to Acremonium, Bipolaris, Curvularia, Nigrospora, Phoma, and other 
genera within the order Pleosporales and the class Dothideomycetes. These results support previous research suggesting that decomposition of plant residues by DSE represents a pathway for the increased nutrition of their host plants. Growth promotion of Aspargus officinalis has already been associated with the presence of Phialocephala fortinii and its capacity to degrade organic $\mathrm{P}$ and $\mathrm{N}$ compounds [82]. In other studies, inoculation of rice and tomato plants with DSE increased the efficiency of macro and micronutrient uptake when ground Canavalia ensiformis was supplemented as an N source [13,28].

On the other hand, the genera Curvularia, Nigrospora, and Periconia, among others, have been documented as endophytes of sugarcane seeds [83], suggesting possible vertical transmission of these endophytes, which has already been proven for other plant hosts [84,85]. Previously published works involving the diversity of root-associated fungi in sugarcane $[30,31]$ have not identified the genus Periconia. The occurrence of this species in association with sugarcane tissues was verified by Raza et al. [65] in China. However, our study is the first report of the species P. macrospinosa as endophyte of sugarcane roots in Brazil.

\section{Conclusions}

The isolation of 16 DSE strains from roots of four sugarcane varieties indicates that the symbiosis with DSE fungi occurs naturally in plants of this crop. DSE fungal species associated with sugarcane belong to genera such as Curvularia, Nigrospora, Periconia, Poaceascoma, and Phialocephala, with the predominance of the Pleosporales order. The most isolated species from the sampled sugarcane plants in the region of Quatá, São Paulo, Brazil is Periconia macrospinosa, followed by species within the genera Poaceascoma and Nigropora. Additionally, the sequences of the ACT, TEF, and TUB gene regions obtained in this study will contribute to the bank of sequences available for DSE fungi.

Supplementary Materials: The following are available online at http://www.mdpi.com/1424-2818/12/9/351/s1, Table S1: GenBank accession numbers for ITS, LSU, TEF, ACT, and TUB attributed to the sequences of isolates of the dark septate endophytic fungi isolated from roots of sugarcane plants sampled in the producing region of Quatá, São Paulo, Brazil. Table S2: Sequences retrieved from GenBank according to the closest BLAST results for phylogenetic analysis of dark septate strains isolated from sugarcane plants in Quatá, São Paulo, Brazil. Figure S1: Colonies (left: top view; right: bottom view) of dark septate endophytic fungi isolated from roots of sugarcane plants grown in the Quatá region, São Paulo, Brazil. Codes A111-A126 refer to the identification attributed at the Center of Biological Resources Johanna Döbereiner. Figure S2: Phylogenetic tree of the ACT gene of dark septate endophytic fungi isolated from sugarcane roots (in bold) and similar sequences from GenBank. Tree inferred by the maximum likelihood method and general time reversible model with the highest log likelihood (-7458.02). Branch lengths analysis involved 30 nucleotide sequences of a total of 1478 positions in dataset. Numbers next to the branches indicate the percentage of replicate trees in which the associated taxa clustered together (5000 replicates bootstrap test). Figure S3: Phylogenetic tree of the TEF gene of dark septate endophytic fungi isolated from sugarcane roots (in bold) and similar sequences from GenBank. Tree inferred by the maximum likelihood method and general time reversible model with the highest log likelihood $(-10,583.33)$. Branch lengths analysis involved 32 nucleotide sequences of a total of 1560 positions in dataset. Numbers next to the branches indicate the percentage of replicate trees in which the associated taxa clustered together (5000 replicates bootstrap test). Figure S4: Phylogenetic tree of the TUB gene of dark septate endophytic fungi isolated from sugarcane roots (in bold) and similar sequences from GenBank. Tree inferred by the maximum likelihood method and general time reversible model with the highest log likelihood (-3937.95). Branch lengths analysis involved 24 nucleotide sequences of a total of 719 positions in dataset. Numbers next to the branches indicate the percentage of replicate trees in which the associated taxa clustered together (5000 replicates bootstrap test).

Author Contributions: Conceptualization, O.J.S.-J.; Methodology, C.M.P., O.J.S.-J., and R.O.F.; Validation, R.O.F.; Formal analysis, R.O.F.; Investigation, R.O.F.; Resources, O.J.S.-J.; Data curation, C.M.P., O.J.S.-J., and R.O.F.; Writing-original draft, R.O.F.; Writing-review and Editing, C.M.P.; O.J.S.-J., M.A.C.C., and R.L.L.B.; Visualization, C.M.P.; O.J.S.-J., and R.O.F.; Supervision, O.J.S.-J. and R.L.L.B.; Project administration, O.J.S.-J.; Funding acquisition, O.J.S.-J. and R.L.L.B. All authors have read and agreed to the published version of the manuscript.

Funding: This work was funded by CAPES-PROEX Brazil through grant concession to R.O.F (2016-2020); Contract for the Provision of Agricultural Research and Development Services between Companhia Agrícola Quatá, Embrapa Agrobiologia and Fundação Arthur Bernardes (D.O.U. of 25-Feb-2015, Section 3 page 5); and Project No. 11.15.02.001.04.02.001 of Embrapa.

Acknowledgments: The authors would like to acknowledge Zilor Açucareira Quatá S/A for supporting the sampling process of sugarcane plants for this research; and Itamar I. García and Fernanda Dourado, from Embrapa Agrobiology, Brazil, for the technical support. 
Conflicts of Interest: The authors declare no conflict of interest. The funders had no role in the design of the study; in the collection, analyses, or interpretation of data; in the writing of the manuscript; or in the decision to publish the results.

\section{References}

1. Grünig, C.R.; Queloz, V.; Sieber, T.N. Structure of Diversity in Dark Septate Endophytes: From Species to Genes. In Endophytes of Forest Trees: Biology and Applications; Pirttilä, A.M., Frank, A.C., Eds.; Forestry Sciences; Springer: Dordrecht, The Netherlands, 2011; pp. 3-30, ISBN 978-94-007-1599-8.

2. Ruotsalainen, A.L. Dark Septate Endophytes (DSE) in Boreal and Subarctic Forests. In Endophytes of Forest Trees; Pirttilä, A.M., Frank, A.C., Eds.; Springer International Publishing: Cham, Switzerland, 2018; Volume 86, pp. 105-117, ISBN 978-3-319-89832-2.

3. Rodriguez, R.J.; White, J.F., Jr.; Arnold, A.E.; Redman, R.S. Fungal endophytes: Diversity and functional roles. New Phytol. 2009, 182, 314-330. [CrossRef]

4. Jumpponen, A.; Trappe, J.M. Dark septate endophytes: A review of facultative biotrophic root-colonizing fungi. New Phytol. 1998, 140, 295-310. [CrossRef]

5. Berthelot, C.; Chalot, M.; Leyval, C.; Blaudez, D. From Darkness to Light: Emergence of the Mysterious Dark Septate Endophytes in Plant Growth Promotion and Stress Alleviation. In Endophytes for a Growing World; Hodkinson, T.R., Doohan, F.M., Saunders, M.J., Murphy, B.R., Eds.; Cambridge University Press: Cambridge, UK, 2019; pp. 143-164, ISBN 978-1-108-60766-7.

6. Mandyam, K.G.; Jumpponen, A. Mutualism-parasitism paradigm synthesized from results of root-endophyte models. Front. Microbiol. 2015, 5. [CrossRef] [PubMed]

7. Knapp, D.G.; Kovács, G.M.; Zajta, E.; Groenewald, J.Z.; Crous, P.W. Dark septate endophytic pleosporalean genera from semiarid areas. Pers. Mol. Phylogeny Evol. Fungi 2015, 35, 87-100. [CrossRef] [PubMed]

8. Bonfim, J.A.; Vasconcellos, R.L.F.; Baldesin, L.F.; Sieber, T.N.; Cardoso, E.J.B.N. Dark septate endophytic fungi of native plants along an altitudinal gradient in the Brazilian Atlantic forest. Fungal Ecol. 2016, 20, 202-210. [CrossRef]

9. Hou, L.; He, X.; Li, X.; Wang, S.; Zhao, L. Species composition and colonization of dark septate endophytes are affected by host plant species and soil depth in the Mu Us sandland, northwest China. Fungal Ecol. 2019, 39, 276-284. [CrossRef]

10. Knapp, D.G.; Pintye, A.; Kovács, G.M. The Dark Side Is Not Fastidious-Dark Septate Endophytic Fungi of Native and Invasive Plants of Semiarid Sandy Areas. PLoS ONE 2012, 7, e32570. [CrossRef]

11. Mandyam, K.; Fox, C.; Jumpponen, A. Septate endophyte colonization and host responses of grasses and forbs native to a tallgrass prairie. Mycorrhiza 2012, 22, 109-119. [CrossRef]

12. Mandyam, K.; Loughin, T.; Jumpponen, A. Isolation and morphological and metabolic characterization of common endophytes in annually burned tallgrass prairie. Mycologia 2010, 102, 813-821. [CrossRef]

13. Vergara, C.; Araujo, K.E.C.; Urquiaga, S.; Schultz, N.; Balieiro, F.d.C.; Medeiros, P.S.; Santos, L.A.; Xavier, G.R.; Zilli, J.E. Dark Septate Endophytic Fungi Help Tomato to Acquire Nutrients from Ground Plant Material. Front. Microbiol. 2017, 8. [CrossRef]

14. Xu, R.; Li, T.; Shen, M.; Yang, Z.L.; Zhao, Z.-W. Evidence for a Dark Septate Endophyte (Exophiala Pisciphila, H93) Enhancing Phosphorus Absorption by Maize Seedlings. Plant Soil 2020, 452, 249-266. [CrossRef]

15. Santos, S.G.; Silva, P.R.A.; Garcia, A.C.; Zilli, J.É.; Berbara, R.L.L. Dark septate endophyte decreases stress on rice plants. Braz. J. Microbiol. 2017, 48, 333-341. [CrossRef] [PubMed]

16. Li, X.; He, X.-L.; Zhou, Y.; Hou, Y.-T.; Zuo, Y.-L. Effects of Dark Septate Endophytes on the Performance of Hedysarum scoparium Under Water Deficit Stress. Front. Plant. Sci. 2019, 10. [CrossRef] [PubMed]

17. Li, T.; Liu, M.J.; Zhang, X.T.; Zhang, H.B.; Sha, T.; Zhao, Z.W. Improved tolerance of maize (Zea mays L.) to heavy metals by colonization of a dark septate endophyte (DSE) Exophiala pisciphila. Sci. Total Environ. 2011, 409, 1069-1074. [CrossRef] [PubMed]

18. Likar, M.; Regvar, M. Isolates of dark septate endophytes reduce metal uptake and improve physiology of Salix caprea L. Plant Soil 2013, 370, 593-604. [CrossRef]

19. Gonzalez Mateu, M.; Baldwin, A.H.; Maul, J.E.; Yarwood, S.A. Dark septate endophyte improves salt tolerance of native and invasive lineages of Phragmites australis. ISME J. 2020, 14, 1943-1954. [CrossRef] 
20. Narisawa, K.; Usuki, F.; Hashiba, T. Control of Verticillium Yellows in Chinese Cabbage by the Dark Septate Endophytic Fungus LtVB3. Phytopathology 2004, 94, 412-418. [CrossRef]

21. Deng, X.; Song, X.; Halifu, S.; Yu, W.; Song, R. Effects of Dark Septate Endophytes Strain A024 on Damping-off Biocontrol, Plant Growth and the Rhizosphere Soil Enviroment of Pinus sylvestris var. mongolica Annual Seedlings. Plants 2020, 9, 913. [CrossRef]

22. Harsonowati, W.; Marian, M.; Surono; Narisawa, K. The Effectiveness of a Dark Septate Endophytic Fungus, Cladophialophora chaetospira SK51, to Mitigate Strawberry Fusarium Wilt Disease and With Growth Promotion Activities. Front. Microbiol. 2020, 11. [CrossRef]

23. Mandyam, K.G.; Roe, J.; Jumpponen, A. Arabidopsis thaliana model system reveals a continuum of responses to root endophyte colonization. Fungal Biol. 2013, 117, 250-260. [CrossRef]

24. Rothen, C.; Miranda, V.; Aranda-Rickert, A.; Fracchia, S.; Rodríguez, M.A. Characterization of dark septate endophyte fungi associated with cultivated soybean at two growth stages. Appl. Soil Ecol. 2017, 120, 62-69. [CrossRef]

25. Mayerhofer, M.S.; Kernaghan, G.; Harper, K.A. The effects of fungal root endophytes on plant growth: A meta-analysis. Mycorrhiza 2013, 23, 119-128. [CrossRef] [PubMed]

26. Berthelot, C.; Blaudez, D.; Leyval, C. Differential growth promotion of poplar and birch inoculated with three dark septate endophytes in two trace element-contaminated soils. Int. J. Phytoremediat. 2017, 19, 1118-1125. [CrossRef] [PubMed]

27. Hulse, J.D. First Report of Dark Septate Endophytes imaged in Cucurbita maxima grown in the Eastern United States. Acta Sci. Agric. 2018, 2, 61-64.

28. Vergara, C.; Araujo, K.E.C.; Urquiaga, S.; Santa-Catarina, C.; Schultz, N.; Silva Araújo, E.; Carvalho Balieiro, F.; Xavier, G.R.; Zilli, J.É. Dark Septate Endophytic Fungi Increase Green Manure-15N Recovery Efficiency, N Contents, and Micronutrients in Rice Grains. Front. Plant. Sci. 2018, 9. [CrossRef]

29. Rudorff, B.F.T.; Aguiar, D.A.; Silva, W.F.; Sugawara, L.M.; Adami, M.; Moreira, M.A. Studies on the Rapid Expansion of Sugarcane for Ethanol Production in São Paulo State (Brazil) Using Landsat Data. Remote Sens. 2010, 2, 1057-1076. [CrossRef]

30. Romão-Dumaresq, A.S.; Dourado, M.N.; de Lima Fávaro, L.C.; Mendes, R.; Ferreira, A.; Araújo, W.L. Diversity of Cultivated Fungi Associated with Conventional and Transgenic Sugarcane and the Interaction between Endophytic Trichoderma virens and the Host Plant. PLoS ONE 2016, 11, e0158974. [CrossRef]

31. Souza, R.S.C.; Okura, V.K.; Armanhi, J.S.L.; Jorrín, B.; Lozano, N.; Silva, M.J.; González-Guerrero, M.; Araújo, L.M.; Verza, N.C.; Bagheri, H.C.; et al. Unlocking the bacterial and fungal communities assemblages of sugarcane microbiome. Sci. Rep. 2016, 6, 28774. [CrossRef]

32. Claassens, A.; Nock, C.J.; Rose, M.T.; Zwieten, L.V.; Rose, T.J. Colonisation dynamics of arbuscular mycorrhizal fungi and dark septate endophytes in the sugarcane crop cycle. Rhizosphere 2018, 7, 18-26. [CrossRef]

33. Fors, R.O.; Júnior, O.J.S.; Carneiro, M.A.C.; Berbara, R.L.L. Selection of arbuscular mycorrhizal fungi for sugarcane in four soils with the presence of dark septate endophytes. Acta Sci. Agron. 2020, 42, e42477. [CrossRef]

34. Santos, H.G.; Jacomine, P.K.T.; Anjos, L.H.C.; Oliveira, V.A.; Lumbreras, J.F.; Coelho, M.R.; Almeida, J.A.; Araujo Filho, J.C.; Oliveira, J.B.; Cunha, T.J.F. Sistema Brasileiro de Classificação de Solos; Embrapa: Brasília, Brazil, 2018; ISBN 978-85-7035-817-2.

35. Ribeiro, K.G.; Pereira, G.M.D.; Mosqueira, C.A.; Baraúna, A.C.; Vital, M.J.S.; Silva, K.; Zilli, J.É. Isolamento, armazenamento e determinação da colonização por fungos "dark septate" a partir de plantas de arroz. Rev. Agrombiente Online 2011, 5, 97-105. [CrossRef]

36. Silvani, V.A.; Fracchia, S.; Fernández, L.; Pérgola, M.; Godeas, A. A simple method to obtain endophytic microorganisms from field-collected roots. Soil Biol. Biochem. 2008, 40, 1259-1263. [CrossRef]

37. Novais, C.B.; Borges, W.L.; Silva, G.A.; Saggin-Júnior, O.J. Técnicas Básicas em Micorrizas Arbusculares; UFLA: Lavras, Brazil, 2017; ISBN 978-85-8127-062-3.

38. White, T.J.; Bruns, T.; Lee, S.; Taylor, J. Amplification and direct sequencing of fungal ribosomal IRNA genes for phylogenetics. In PCR Protocols; Innis, M.A., Gelfand, D.H., Sninsky, J.J., White, T.J., Eds.; Academic Press: San Diego, CA, USA, 1990; pp. 315-322, ISBN 978-0-12-372180-8.

39. Rehner, S.A.; Samuels, G.J. Taxonomy and phylogeny of Gliocladium analysed from nuclear large subunit ribosomal DNA sequences. Mycol. Res. 1994, 98, 625-634. [CrossRef]

40. Vilgalys, R.; Hester, M. Rapid genetic identification and mapping of enzymatically amplified ribosomal DNA from several Cryptococcus species. J. Bacteriol. 1990, 172, 4238-4246. [CrossRef] [PubMed] 
41. Carbone, I.; Kohn, L.M. A Method for Designing Primer Sets for Speciation Studies in Filamentous Ascomycetes. Mycologia 1999, 91, 553-556. [CrossRef]

42. Groenewald, J.Z.; Nakashima, C.; Nishikawa, J.; Shin, H.-D.; Park, J.-H.; Jama, A.N.; Groenewald, M.; Braun, U.; Crous, P.W. Species concepts in Cercospora: Spotting the weeds among the roses. Stud. Mycol. 2013, 75, 115-170. [CrossRef] [PubMed]

43. Glass, N.L.; Donaldson, G.C. Development of primer sets designed for use with the PCR to amplify conserved genes from filamentous ascomycetes. Appl. Environ. Microbiol. 1995, 61, 1323-1330. [CrossRef]

44. European and Mediterranean Plant Protection Organization (EPPO) Q-Bank. Available online: https: //qbank.eppo.int/fungi/ (accessed on 13 February 2019).

45. Morgulis, A.; Coulouris, G.; Raytselis, Y.; Madden, T.L.; Agarwala, R.; Schäffer, A.A. Database indexing for production MegaBLAST searches. Bioinformatics 2008, 24, 1757-1764. [CrossRef]

46. Zhang, Z.; Schwartz, S.; Wagner, L.; Miller, W. A greedy algorithm for aligning DNA sequences. J. Comput. Biol. J. Comput. Mol. Cell Biol. 2000, 7, 203-214. [CrossRef]

47. Kumar, S.; Stecher, G.; Li, M.; Knyaz, C.; Tamura, K. MEGA X: Molecular Evolutionary Genetics Analysis across Computing Platforms. Mol. Biol. Evol. 2018, 35, 1547-1549. [CrossRef]

48. Nei, M.; Kumar, S. Molecular Evolution and Phylogenetics; Oxford University Press: New York, NY, USA, 2000; ISBN 9780195135855.

49. MycoBank Database. Available online: https://www.mycobank.org/ (accessed on 17 June 2020).

50. Index Fungorum. Available online: http://www.indexfungorum.org/Names/Names.asp (accessed on 17 June 2020).

51. Ali-Shtayeh, M.S.; Jamous, R.M.; Yaghmour, R.M.-R. Mycology Manual; An-Najah National University: Nablus, Palestine, 1998.

52. Lin, W.; Wu, L.; Lin, S.; Zhang, A.; Zhou, M.; Lin, R.; Wang, H.; Chen, J.; Zhang, Z.; Lin, R. Metaproteomic analysis of ratoon sugarcane rhizospheric soil. BMC Microbiol. 2013, 13, 135. [CrossRef] [PubMed]

53. Li, X.; He, C.; He, X.; Su, F.; Hou, L.; Ren, Y.; Hou, Y. Dark septate endophytes improve the growth of host and non-host plants under drought stress through altered root development. Plant Soil 2019, 439, 259-272. [CrossRef]

54. Yuan, Z.-L.; Zhang, C.-L.; Lin, F.-C.; Kubicek, C.P. Identity, Diversity, and Molecular Phylogeny of the Endophytic Mycobiota in the Roots of Rare Wild Rice (Oryza granulate) from a Nature Reserve in Yunnan, China. Appl. Environ. Microbiol. 2010, 76, 1642-1652. [CrossRef] [PubMed]

55. Loro, M.; Valero-Jiménez, C.A.; Nozawa, S.; Márquez, L.M. Diversity and composition of fungal endophytes in semiarid Northwest Venezuela. J. Arid Environ. 2012, 85, 46-55. [CrossRef]

56. Ellis, M.B. Periconia macrospinosa. Descriptions of Fungi and Bacteria. IMI Descr. Fungi Bact. 1968, $17,168$.

57. Herrera, J.; Poudel, R.; Bokati, D. Assessment of root-associated fungal communities colonizing two species of tropical grasses reveals incongruence to fungal communities of North American native grasses. Fungal Ecol. 2013, 6, 65-69. [CrossRef]

58. Lima, A.; Furtado, M. Espécies do género Curvularia (fungos anamórficos: Hyphomycetes) na ilha de Santiago, Cabo Verde. Port. Acta Biol. 2007, 22, 145-156.

59. Manamgoda, D.S.; Cai, L.; McKenzie, E.H.C.; Crous, P.W.; Madrid, H.; Chukeatirote, E.; Shivas, R.G.; Tan, Y.P.; Hyde, K.D. A phylogenetic and taxonomic re-evaluation of the Bipolaris-Cochliobolus-Curvularia Complex. Fungal Divers. 2012, 56, 131-144. [CrossRef]

60. Liang, Y.; Ran, S.-F.; Bhat, J.; Hyde, K.D.; Wang, Y.; Zhao, D.-G. Curvularia microspora sp. nov. associated with leaf diseases of Hippeastrum striatum in China. MycoKeys 2018, 49-61. [CrossRef]

61. Bengyella, L.; Iftikhar, S.; Nawaz, K.; Fonmboh, D.J.; Yekwa, E.L.; Jones, R.C.; Njanu, Y.M.T.; Roy, P. Biotechnological application of endophytic filamentous Bipolaris and Curvularia: A review on bioeconomy impact. World J. Microbiol. Biotechnol. 2019, 35, 69. [CrossRef]

62. Avinash, K.S.; Ashwini, H.S.; Babu, H.N.R.; Krishnamurthy, Y.L. Antimicrobial Potential of Crude Extract of Curvularia lunata, an Endophytic Fungi Isolated from Cymbopogon caesius. J. Mycol. 2015, 2015, 1-4. [CrossRef]

63. Ricaud, C.; Egan, B.T. (Eds.) Diseases of Sugarcane: Major Diseases; Elsevier: Amsterdam, The Netherlands, 1989; ISBN 0-444-42797-X.

64. Mehnaz, S. Microbes-Friends and foes of sugarcane: Microbes and sugarcane. J. Basic Microbiol. 2013, 53, 954-971. [CrossRef] [PubMed]

65. Raza, M.; Zhang, Z.-F.; Hyde, K.D.; Diao, Y.-Z.; Cai, L. Culturable plant pathogenic fungi associated with sugarcane in southern China. Fungal Divers. 2019, 99, 1-104. [CrossRef] 
66. Tanney, J.B.; Douglas, B.; Seifert, K.A. Sexual and asexual states of some endophytic Phialocephala species of Picea. Mycologia 2016, 108, 255-280. [CrossRef]

67. Wong, P.T.W.; Dong, C.; Martin, P.M.; Sharp, P.J. Fairway patch-A serious emerging disease of couch (syn. bermudagrass) Cynodon dactylon and kikuyu (Pennisetum clandestinum) turf in Australia caused by Phialocephala bamuru P.T.W. Wong \& C. Dong sp. nov. Australas. Plant. Pathol. 2015, 44, 545-555. [CrossRef]

68. Walsh, E.; Luo, J.; Naik, A.; Preteroti, T.; Zhang, N. Barrenia, a new genus associated with roots of switchgrass and pine in the oligotrophic pine barrens. Fungal Biol. 2015, 119, 1216-1225. [CrossRef]

69. Tanney, J.B.; Seifert, K.A. Mollisiaceae: An overlooked lineage of diverse endophytes. Stud. Mycol. 2020. [CrossRef]

70. Wang, M.; Liu, F.; Crous, P.W.; Cai, L. Phylogenetic reassessment of Nigrospora: Ubiquitous endophytes, plant and human pathogens. Persoonia 2017, 39, 118-142. [CrossRef]

71. Hao, Y.; Aluthmuhandiram, J.V.S.; Chethana, K.W.T.; Manawasinghe, I.S.; Li, X.; Liu, M.; Hyde, K.D.; Phillips, A.J.L.; Zhang, W. Nigrospora Species Associated with Various Hosts from Shandong Peninsula, China. Mycobiology 2020, 48, 169-183. [CrossRef]

72. Zhao, J.H.; Zhang, Y.L.; Wang, L.W.; Wang, J.Y.; Zhang, C.L. Bioactive secondary metabolites from Nigrospora sp. LLGLM003, an endophytic fungus of the medicinal plant Moringa oleifera Lam. World J. Microbiol. Biotechnol. 2012, 28, 2107-2112. [CrossRef] [PubMed]

73. Sun, X.; Cai, X.; Pang, Q.; Zhou, M.; Chen, Y.; Zhang, W.; Bian, Q. First Report of Leaf Blight on Mentha canadensis Caused by Nigrospora sphaerica in China. Plant. Dis. 2020. [CrossRef]

74. Chen, X.; Wang, N.; Yang, M.-F.; Li, H.-X. First Report of Nigrospora Leaf Spot Caused by Nigrospora oryzae on Watermelon in China. Plant. Dis. 2018, 103, 1019. [CrossRef]

75. Cui, Y.P.; Wu, B.; Peng, A.T.; Li, Z.L.; Lin, J.F.; Song, X.B. First Report of Nigrospora Leaf Blight on Sugarcane Caused by Nigrospora sphaerica in China. Plant. Dis. 2017, 102, 824. [CrossRef]

76. Schoch, C.L.; Seifert, K.A.; Huhndorf, S.; Robert, V.; Spouge, J.L.; Levesque, C.A.; Chen, W.; Consortium, F.B. Nuclear ribosomal internal transcribed spacer (ITS) region as a universal DNA barcode marker for Fungi. Proc. Natl. Acad. Sci. USA 2012, 109, 6241-6246. [CrossRef] [PubMed]

77. Samson, R.A.; Visagie, C.M.; Houbraken, J.; Hong, S.-B.; Hubka, V.; Klaassen, C.H.W.; Perrone, G.; Seifert, K.A.; Susca, A.; Tanney, J.B.; et al. Phylogeny, identification and nomenclature of the genus Aspergillus. Stud. Mycol. 2014, 78, 141-173. [CrossRef] [PubMed]

78. Raja, H.A.; Miller, A.N.; Pearce, C.J.; Oberlies, N.H. Fungal Identification Using Molecular Tools: A Primer for the Natural Products Research Community. J. Nat. Prod. 2017, 80, 756-770. [CrossRef]

79. Visagie, C.M.; Houbraken, J.; Frisvad, J.C.; Hong, S.-B.; Klaassen, C.H.W.; Perrone, G.; Seifert, K.A.; Varga, J.; Yaguchi, T.; Samson, R.A. Identification and nomenclature of the genus Penicillium. Stud. Mycol. 2014, 78, 343-371. [CrossRef] [PubMed]

80. Baum, C.; Hrynkiewicz, K.; Szymańska, S.; Vitow, N.; Hoeber, S.; Fransson, P.M.A.; Weih, M. Mixture of Salix Genotypes Promotes Root Colonization with Dark Septate Endophytes and Changes P Cycling in the Mycorrhizosphere. Front. Microbiol. 2018, 9. [CrossRef]

81. Shrestha, P.; Szaro, T.M.; Bruns, T.D.; Taylor, J.W. Systematic Search for Cultivatable Fungi That Best Deconstruct Cell Walls of Miscanthus and Sugarcane in the Field. Appl. Environ. Microbiol. 2011, 77, 5490-5504. [CrossRef]

82. Surono; Narisawa, K. The dark septate endophytic fungus Phialocephala fortinii is a potential decomposer of soil organic compounds and a promoter of Asparagus officinalis growth. Fungal Ecol. 2017, 28, 1-10. [CrossRef]

83. Martins, T.D.; Menten, J.O.M.; Sanguino, Á. Fungos associados às sementes (Cariopses) de cana-de-açúcar: Métodos para detecção, incidência e relação entre incidência fúngica e ambiente de produção das sementes. Summa Phytopathol. 2009, 35, 173-178. [CrossRef]

84. Hardoim, P.R.; Hardoim, C.C.P.; van Overbeek, L.S.; van Elsas, J.D. Dynamics of Seed-Borne Rice Endophytes on Early Plant Growth Stages. PLoS ONE 2012, 7, e30438. [CrossRef] [PubMed]

85. Hardoim, P.R.; Overbeek, L.S.; Elsas, J.D. Properties of bacterial endophytes and their proposed role in plant growth. Trends Microbiol. 2008, 16, 463-471. [CrossRef] [PubMed]

(C) 2020 by the authors. Licensee MDPI, Basel, Switzerland. This article is an open access article distributed under the terms and conditions of the Creative Commons Attribution (CC BY) license (http://creativecommons.org/licenses/by/4.0/). 